أثر المشروعات الصغيرة على الجواتب الاقتصادية والاجتماعية للأسر الريفية دراسة ميدانية ببعض قرى محافظتي كفر الثيخ و الغربية

$$
\text { إيناس سمير الشرنوبى }
$$

- تبين وجود علاقة ارتباط طردية ومعنوية بـين كـل مسن:

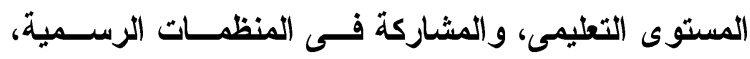

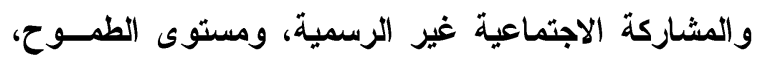

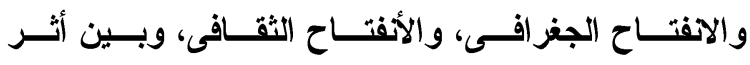
المشروعات الصغيرة على الجاتب الاقتصــادى، والجاتـب ولئ

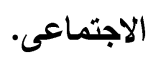

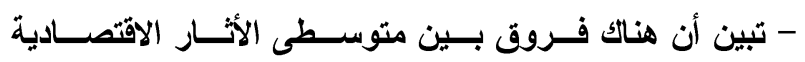
و الاجتماعية للمشروعات الصغيرة لصالح المتزوجين.

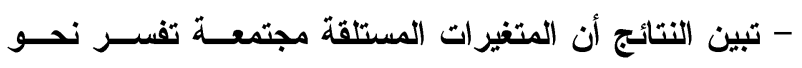

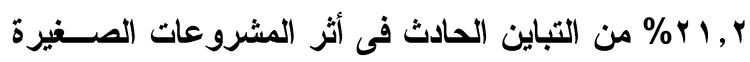

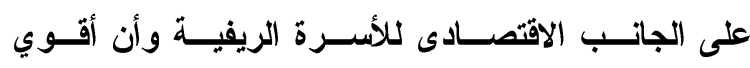

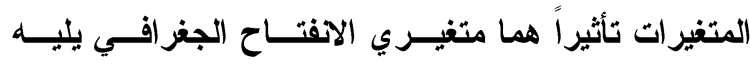

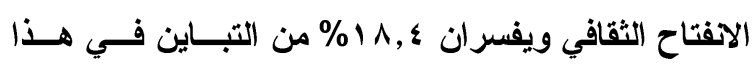

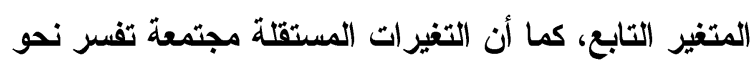

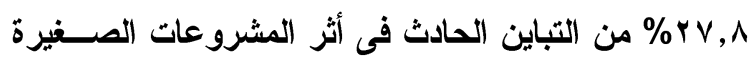

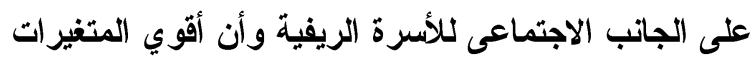

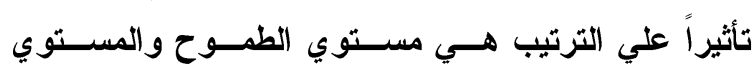

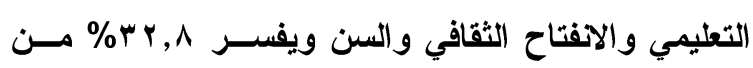
التباين الحادث في هذا المتغير التابع.

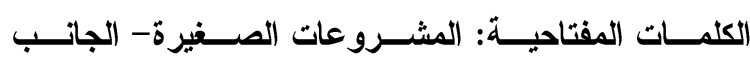
الاقتصادي - الجاتب الاجتماعي المفتاجي المقدمة والمشكلة البحثية

تعد المشروعات الصغيرة مــن أقــوى أدوات التتميــة

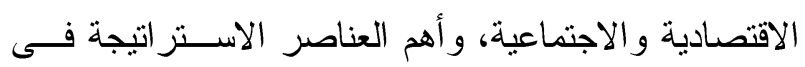

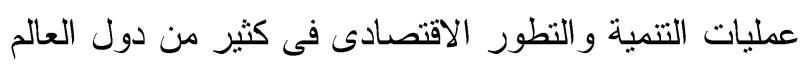

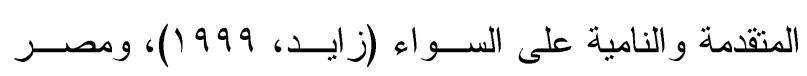

الملخص العربى

استهدف هذا البحث التعرف على أثر المشروعات الصغيرة

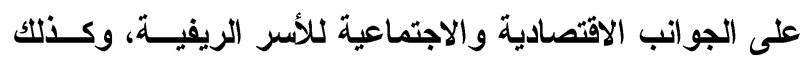

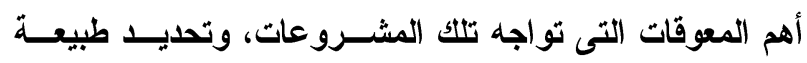
العلاقة بين المتغيرات المستقلة المدروسة(الســن- المســتوى

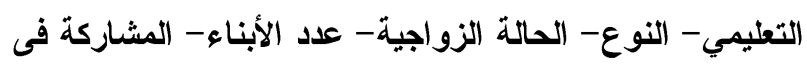

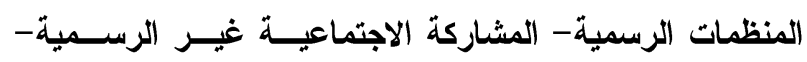

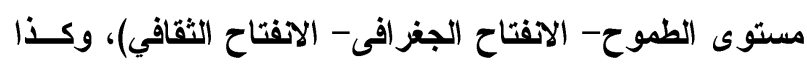

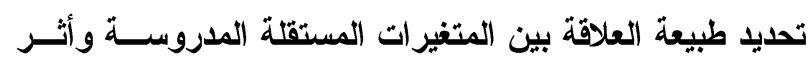

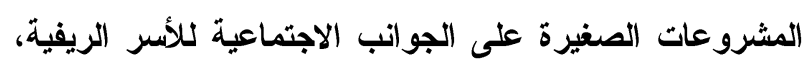

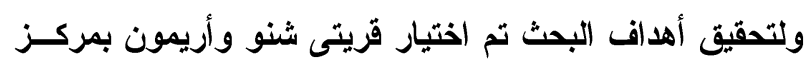

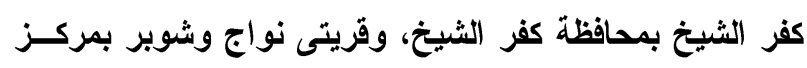

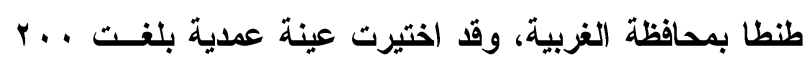

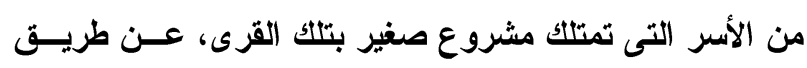

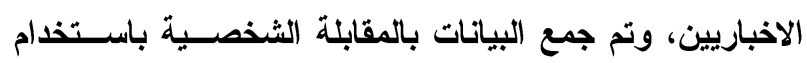

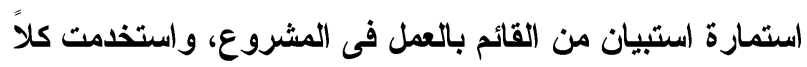

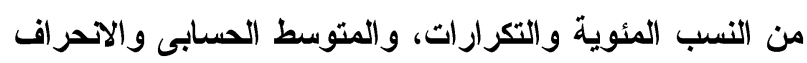
المعيارى، ومعامل الارتباط البسيط (بيرسون) والاحدار المتعدد

$$
\text { واختبار "ت" فى تحليل البياتات. }
$$

وكاتت اهم النتائج التى توصل إليها البحث ما يلى:

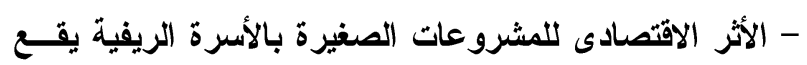

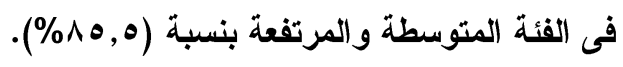

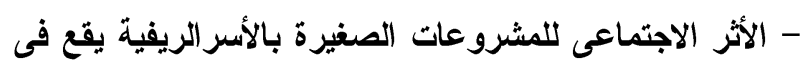

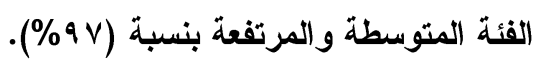

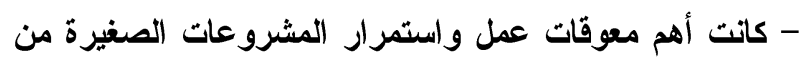
وجهة نظر العاملين بها هـى قلـــة رأس المـال الــلام

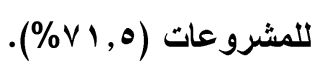




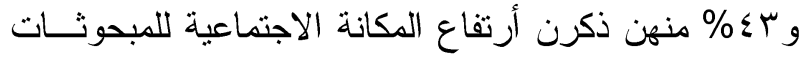

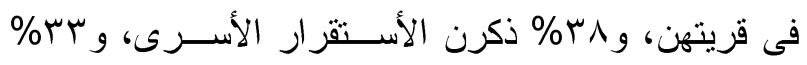
ذكرن الأمان الاقتصادى.

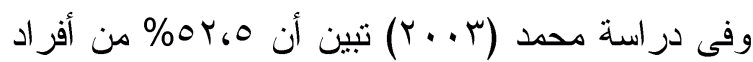

العينة البحثية مشروعاتهم تساهم بدرجة كبيرة فى تتمية كل

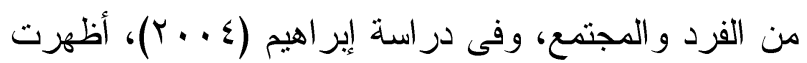

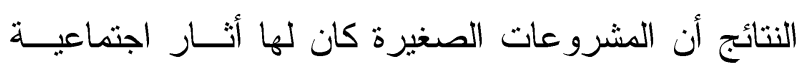
و اقتصادية تمثلت فى ملكية الأجهزة الكهربائية و المنزليــة،

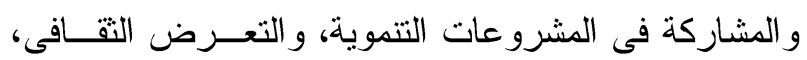
و الاستقرار الفيزيقى، والإدخار، و التغير فى الدخل، و التغير فى الانفاق، وزيادة الميل للاستثمار .

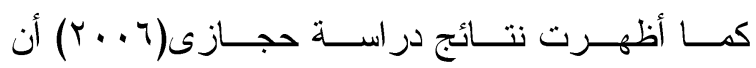

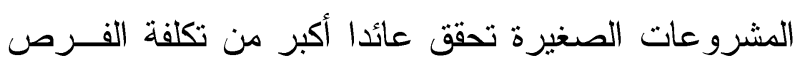

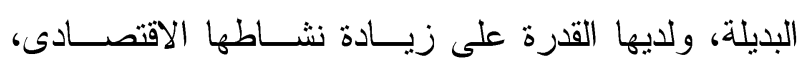
وتحقيق زيادة فى إير ادتها.

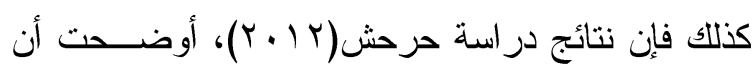
الدور الاقتصادى للمشروعات الصغيرة فى معيشة الأســرة

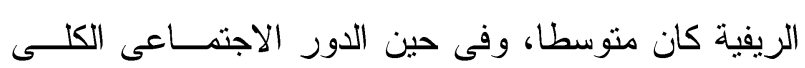
للمشروعات الصغيرة فى تتمية الأسرة الريفية كبيرا.

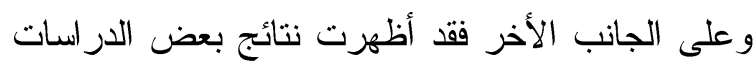
محدودية دور المشروعات الصغيرة فى الجوانب المختلفة،

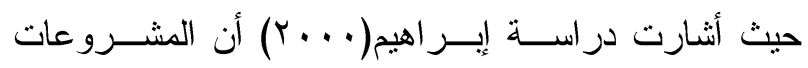

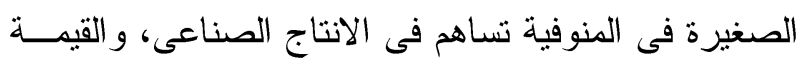

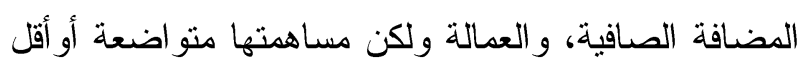
من المتوقع من هذه المشروعات، وفى دراســـة رضــــوان

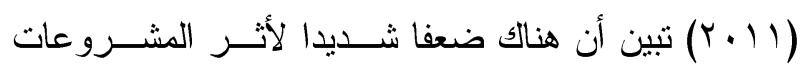

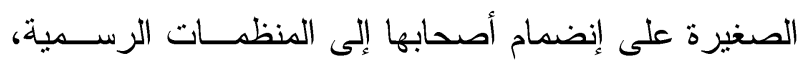

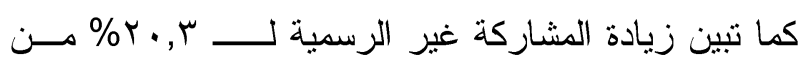
أصحاب المشرعات الصغيرة، وزيادة المشاركة السياســـة الرية لتسع مبحوثين فقط.
كغيرها من دول العالم تعطى للمشروعات الصغيرة أهميــة

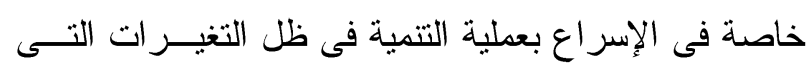

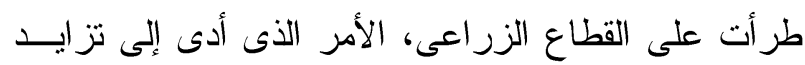

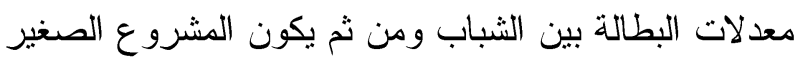

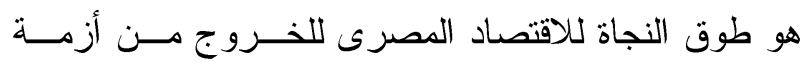

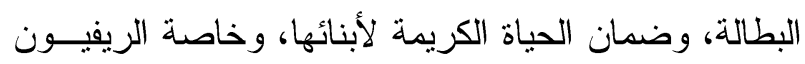

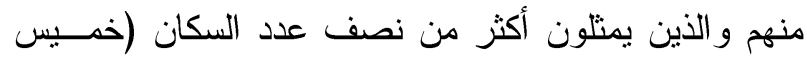
و النجار، .... (Y).

وفى هذ الصدد يؤكد الزقلعى (.... r)، أن للمشروعات الصغيرة دور هام فى محاربة الفقر و البطالة، وفى معالجة الخدمات العامة، وبصفة خاصة الخدمات الصحية و التعليمية ومياه الثرب و الطرق الريفية، وكذلك لها دورا إيجابيا فـى

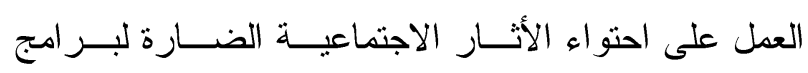

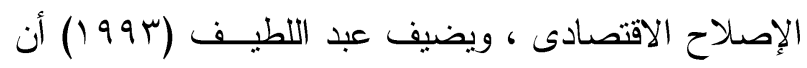

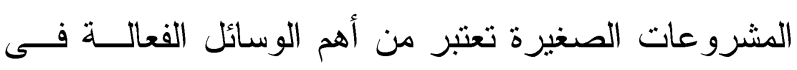
توزيع عائد التنمية بعدالة على الفقراء، وكـذللك الاســتفادة

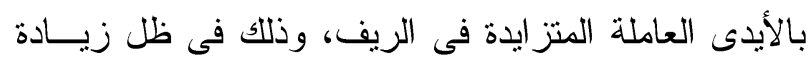

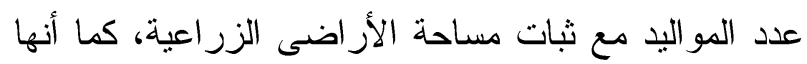

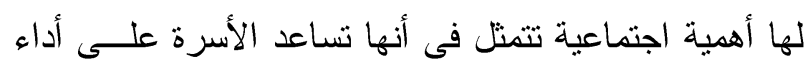
دورها القيادى بجانب زيادة دخل الأسرة بما يساهم بفاعلية

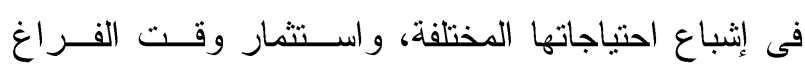

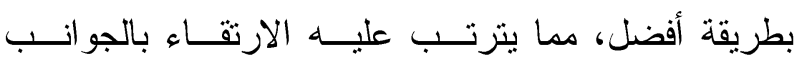
الاقتصادية والاجتماعية للأسر الريفية. وقد توصلت بعض الدراسات إلى نتائج نتؤيـــــــــــام إنهام

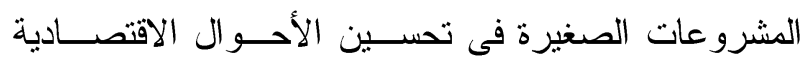
و الاجتماعية للريفيين منها دراسـة (Shames Eldin Et. all)

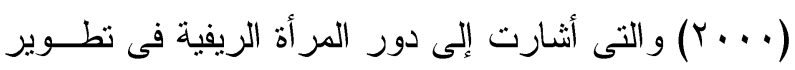
المشروعات الصغيرة باستخدام تكنولوجيا تصنيعية بسيطة،

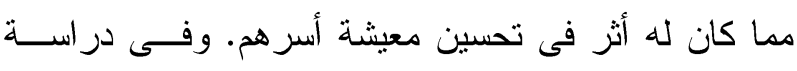

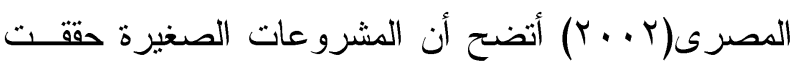
فو ائد متعددة حيث ذكر ، 9\% من المبحوثات زيادة الدخل، 


$$
\text { مجلة الإسكندرية للتبادل العلمى - (مجلدVT العدد ) أكتوبر - ديسمبر } 17 \text {. }
$$

1- توجد علاقة ارتباطية بين كل متغير من (سن صــاحب

المشروع، و المستوي التعليمي لصاحب المشروع، وعدد الابناء، و المشاركه في المنظمات الرسميه، و المشـــاركه الاجتماعيه غير الرسميه، ومستوي الطموح، و الانفتــاح

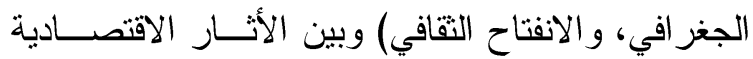
للمشروعات الصغيرة علي الأسر الريفية. r- توجد علاقة ارتباطية متعددة بين المتغيرات المســتقلة المدروسة مجتمعه(سن صاحب المشروع، و المسـتوي

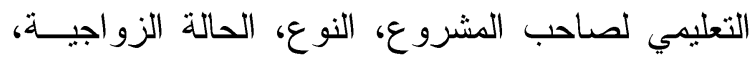
وعدد الابناء، و المشاركه فــي المنظهــات الرســـيه، و المشاركه الاجتماعيه غير الرسميه، ومستوي الطموح، و الانفتاح الجغر افي، و الانفتاح الثقــافي) وبـــين الأثـــار الاقتصادية للمشروعات الصغيرة علي الأسر الريفية. س- توجد فروق بين المبحــــثين فـــي أثــر المشــروعات

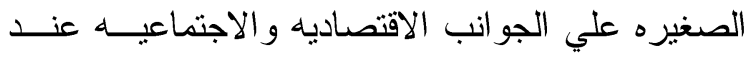
تصنيفهم علي أساس كل من النوع، و الحاله الاجتماعيه. ؟- يسهر كل متغير من المتغير ات المستقلة المدروسة فـي

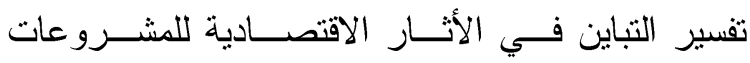
الصغيرة علي الأسر الريفية. 0- توجد علاقة ارتباطية بين المتغيرات المستقلة المدروسة

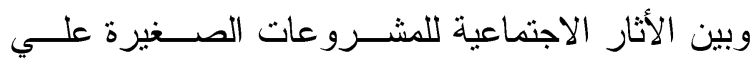

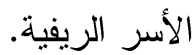
7- توجد علاقة ارتباطية متعددة بين المتغيرات المســقلة

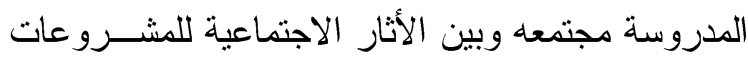
الصغيرة علي الأسر الريفية. - يسهم كل متغير من المتغيرات المستقلة المدروسة فـي

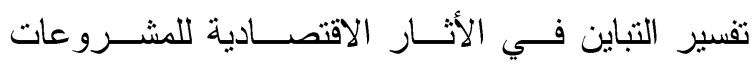
الصغيرة علي الأسر الريفية.
مما سبق يتضح أن الدراسات التى تتاولت المشروعات الصغيرة فى الجوانب المختلفة لم تتفق جميعها على قدر هذا

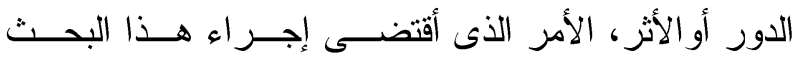
للتعرف على الأثار الاقتصادية والاجتماعية للمشــروعات الصغيرة فى الأسر الريفية.

\section{أهـــــ البحث}

يهدف البحث بصفة رئيسية إلى دراسة الأثار الاقتصادية و الاجتماعية للمشروعات الصغيرة علي الأسر الريفية وذللك من خلال تحقيق الأهداف الفرعية التالية: 1- التعرف على الأثنار الاقتصادية للمشروعات الصـــيرة

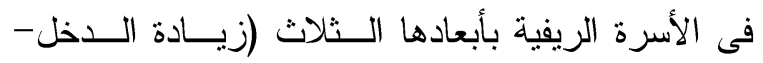
تحسين الانفاق - تتمية القدرة على الإدخار). r- التعرف على الأثار الاجتماعية للمشروعات الصـــيرة فى الأسر الريفية بأبعادها الثلاث (الصحية- التعليميةالمكانة الاجتماعية). بـ- الوقوف على معوقات عمل واسـتـمرار المشــروعات الصغيرة. ـ - در اسة العلاقات الثنائيه بين كل متغير من المتغيـرات المستقلة المدروسة وبين الأثار الاقتصادية والاجتماعية

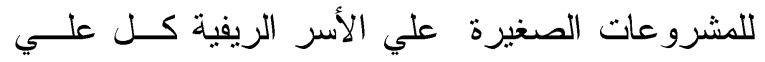
0- تحديد العلاقة بين كل من المتغيرات المستقلة المدروسة مجتمعة وبين كل من الأثار الاقتصــادية و الاجتماعيــة للمشروعات الصغيرة فى الأسر الريفية. ج- تحديد درجة اسهام كل متغير من المتغيرات المسـنقلة المدروسة في تقسير التباين فــي الأثـار الاقتصــادية و الاجتماعية للمشروعات الصغيرة فى الأسر الريفية. القروض البحثية: - ان لتحقيق أهداف البحث الرابع و الخامس و الســادس تــــ صياغة الفروض البحثية الآتية: 


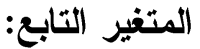

1- أُثر المشروعات الصغيرة على الجانــب الاقتصـــادى

للأسر الريفية: هى التغيرات الاقتصادية الايجابية التـى التى

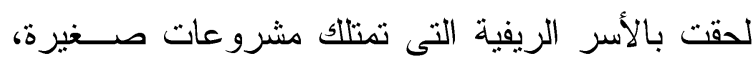
من حيث تحسين الاخل، وتحسين الانفاق، وتتمية القدرة على الادخار ، ونم قياسها باستخدام مقياس رباعى مكون من 17 عبارة موجبه يجيب المبحوث عن كل منها بأحد الاستجابات الآتية: (بدرجة مرتفعة- بدرجة متوســـة

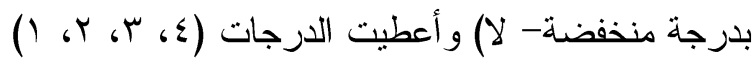
على الترتيب، وقد تراوح المدى النظرى لهــا مــابين

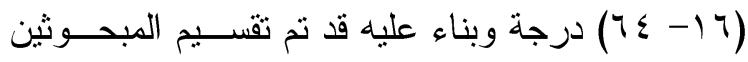
وفقا لأثر المشروعات الصغيرة على الجانب الاقتصادى

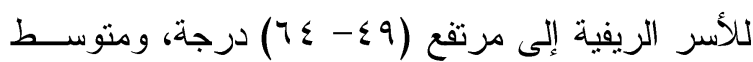
(ץ ( وتضمن الجانب الاقتصادي ثلاث أبعاد رئيسية وهي:أ- تحسين الــدخل: يقصد به التغيرات الإيجابية التى حدثت فى دخل الأسر الريفية من خلال المشروعات الصغيرة

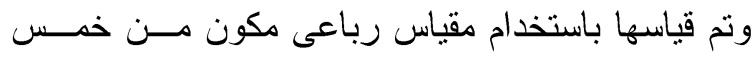
عبار ات يجيب المبحوث عن كل منها بأحد الاستجابات

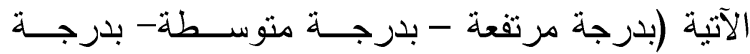

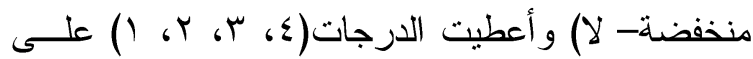
الترتيب وقد تزواح المدى النظرى لها ما بين (0، r) درجة وبناء عليه قد تم تقسيم المبحوثين وفقا لتحســين

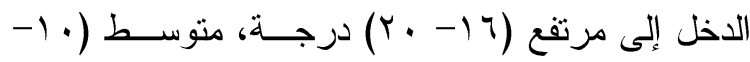
10) درجة، ومنخفض (0-9) درجة.

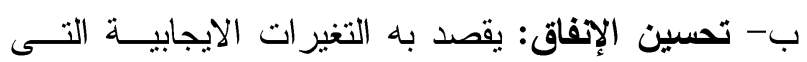
حدثت فى انفاق الأسر الريفية من خلال المشــروعات الصغيرة وتم قياسها باستخدام مقياس رباعى مكون من

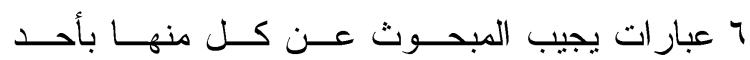
الاستجابات الآتية: (بدرجة مرتفعة- بدرجة متوســـة-

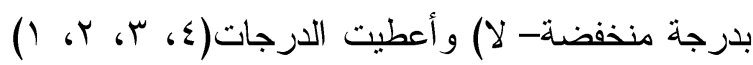

\section{الأسلوب البحثي}

أولاً: منطقة وعينة البحث:

أجرى هذا البحث بمحافظتى كفر الثيخ و الغربية، وقد تم اختيار قريتى شنو وأريمون بمركز كفر الثيخ-محافظة

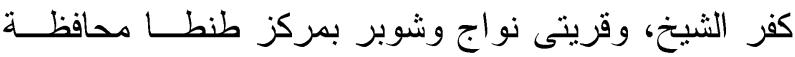
الغربية، وكان الاختيار عشو ائيا لقرى الدراسة، ونظر العدم تو افر قوائم تحدد أصحاب المشروعات الصغيرة، اوبيانات بأسماء أصحاب تلأك المشروعات، فقد اســتعانت الباحثــة بالقاده المحليين الموجودين بالقريسـة فـى التعـرف علـى أصحاب المشروعات الصغيرة. وتم اختيــار ـ0 صـــاحب

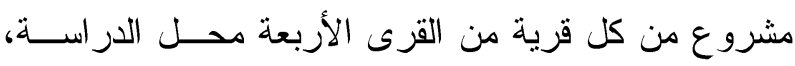
لتصبح إجمالى عينة الدر اسة . . r مفرده. ثانياً: أسلوب جمع البيانات: تم جمع البيانات عن طريق المقابلة الشخصية لأفــراد العينة البحثية باستخدام استمارة بحث تم إعدادها وتحكيمهـا واختبارها مبدئيا و اعدادها في صورتها النهائية حتي تكون صالحة لتحقيق أهداف البحث. ثالثاً: التعريفات الاجر ائية: المشروعات الصغيرة: هى منثــأت فرديـــة تمـــارس نشاطا اقتصاديا انتاجيا أوحرفيا أوتجاريا، ويقل رأس المال المدفوع عن خمسين ألف جنيه و لا يزيد عدد العاملين بهــا عن عشرة عمال. رابعاً: المتغيرات البحثية: المتغير ات المستقلة: اشتمل البحث علي عشرة متغيراً مستقلة وهي السن، و المستوي التعليمي، و النوع، و الحالـــة الزو اجيــة، وعــدد الأبناء، و المشاركة في المنظمــات الرســـية، و المشـــاركة الاجتماعية غير الرسمية، ومستوي الطمــوح، والانفتــاح الجغر افي، و الانفتاح الثقافي. 


$$
\text { مجلة الإسكندرية للتبادل العلمى - (مجلدVT العددء) أكتوبر - ديسمبر } 17 \text { ـ }
$$

وتضمن الجانب الاجتماعي ثلاث أبعاد رئيسية وهي:أ- تصسين المستوى الصحى: يقصد به التغيرات الصــحية

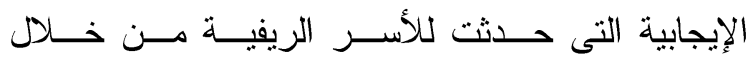
المشروعات الصغيرة وتم قياســــا باســتخدام مقيـــاس رباعى مكون من 9 عبار ات يجيب المبحوث عن كـلـل

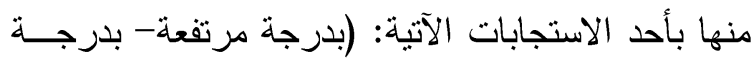

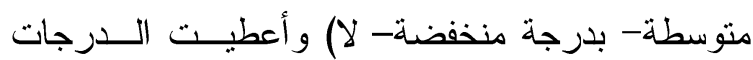

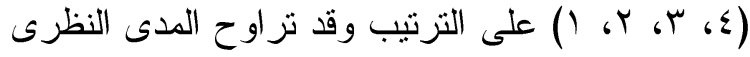

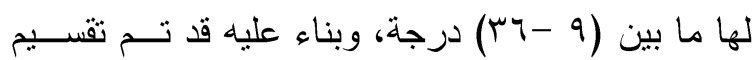

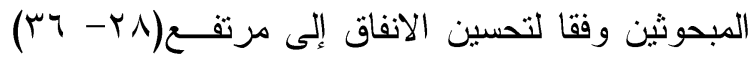

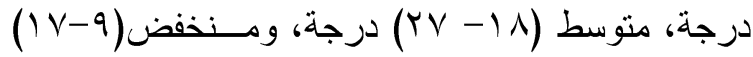
درجة.

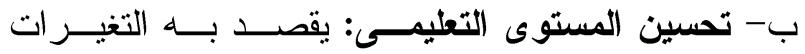
التعليمية الايجايية التى حدثت للأسر الريفية من خــلال المشروعات الصغيرة، وتم قياسها باســتخدام مقيــاس رباعى مكون من ^ عبار ات يجيب المبحوث عن كـلـ منها بأحد الاستجابات الآتية: (بدرجة مرتفعة- بدرجـــة

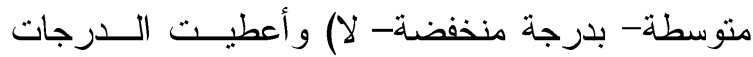

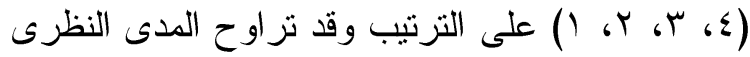

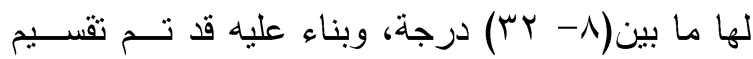

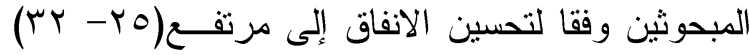

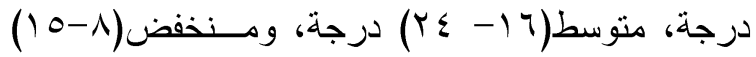
درجة.

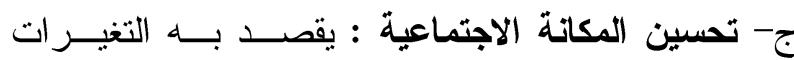
الايجابية للمكانة الاجتماعية التى حدثت للأسر الريفيــة من خلال المشروعات الصغيرة، وتم قياسها باســتخدام مقياس رباعى مكون من V عبار ات يجيب المبحوث عن بن

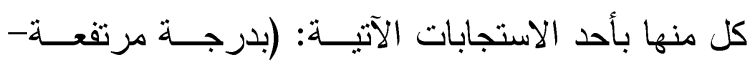

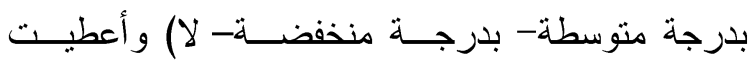

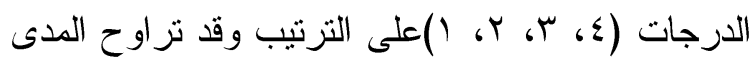

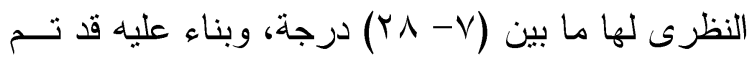

على الترتيب وقد تراوح المدى النظرى لها مـــا بـين (Y (Y ) درجة، وبناء عليه قد نم تقسيم المبحوثين وفقا

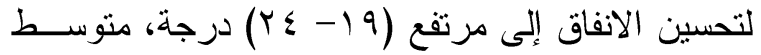

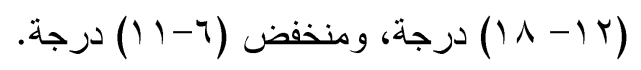
ج- تنمية القدرة على الإدخار : يقصد به التغيرات الإيجابية التى حدثت فى قدرة الأسر الريفية على الادخــار مــن خلال المشروعات الصغيرة، وتـــ قياســـها باســتخدام مقياس رباعى مكون من خمس عبار ات يجيب المبحوث عن كل منها بأحد الاستجابات الآتية: (بدرجة مرتفعة-

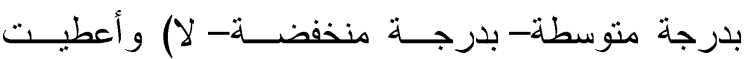
الدرجات(ع، س، r، ( ) على الترنيب وقد ترواح المدى

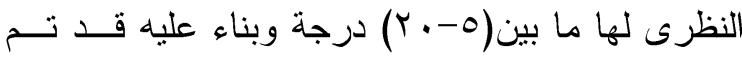
تقسيم المبحوثين وفقا لتتمية القدرة على الادخـــار إلــى

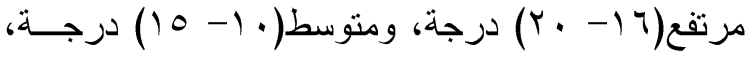
ومنخفض(0 - 9) درجة.

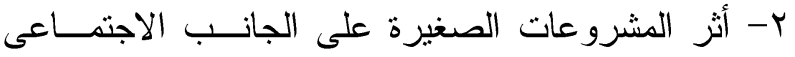
للأسر الريفية: وهى التغيرات الاجتماعية الايجابية التى لحقت بالأسر الريفية التى تمتلك مشروعات صـــــيرة، من حيث تحسين المستوى الصحى، وتحسين المســتوى

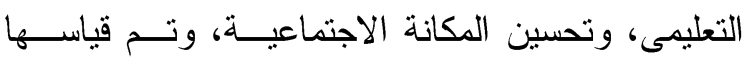
باستخدام مقياس رباعى مكون من ؟r عبــارة موجبــة يجيب المبحوث عن كل منها بأحد الاستجابات الآتيــة: (بدرجة مرتفعة- بدرجة متوسطة- بدرجة منخفضــــلا) و أعطيت الدرجات(ع، ب، r r، () على الترتيب وقد تزاوح المدى النظرى لها ما بــين(ع ب- 9 9) درجــة، وبناء عليه قد تم تقسيم المبحوثين وفقا لأثز المشروعات

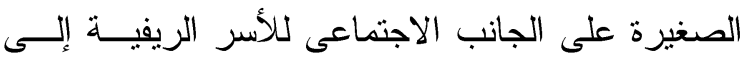
مرتفع(Yr-

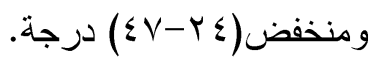


فى المنظمات الرسمية (\%०,0V) ومشاركة اجتماعية غير

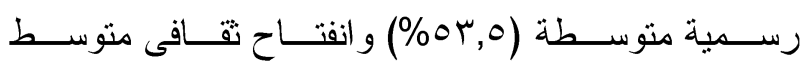

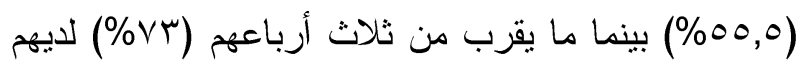

$$
\text { انفتاح جغر افى متوسط. }
$$

r - أثر المشروعات الصغيرة على الجانــب الاقتصــادى

\section{لكلأسر الريفية}

يعرض جدول(r) توزيع عينــة البحــث وفقـــا لأثــر

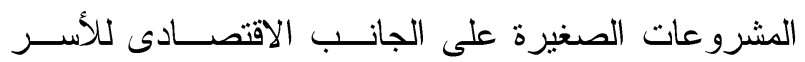

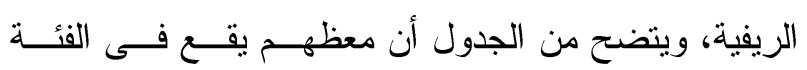

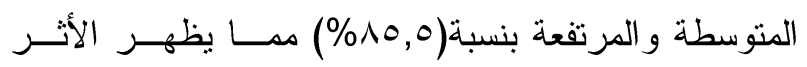

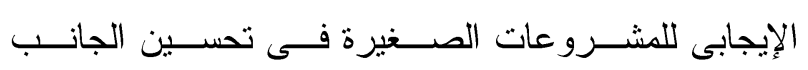

الاقتصادى لتلك الأسر •

وباستعر اض النتائج البحثية للأبعــاد الــثلاث للجانـبـ

الاقتصادى اتضـح ما يلى:

أ- تحسين الاخل:

يعرض جدول(r) توزيع عينة البحث وفقا لتحسين دخل

الأسر الريفية العاملة بالمشروعات الصغيرة ويتضح منها توزي

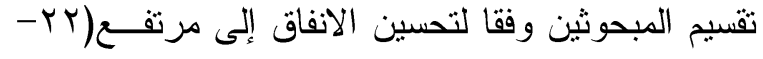

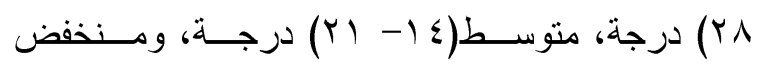

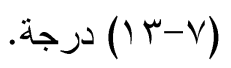

\section{النتائج البحثية ومناقشتها}

يعرض هذا الجزء النتائج المتحصل عليهـــا ومناقثــنها لكل من المتغيرات البحثية المستقلة المدروسة، وكذلك أثــر المشروعات الصغيرة على الجوانب الاقتصادية و الاجتماعية

لنأسر الريفية. ا - وصف عينة البحث:

يعرض جدول(1) توزيع عينة البحث وفقا للمتغيـرات المستقلة للار اسة، ويتضح منه أن ما يقرب من خمسي أفر اد العينة فى الفئة العمرية المتوسطة (9,0ب\%) وحو الى ثلاث أرباع أفر اد العينة حاصلين على شهادات تعليمية (متوسط- وأه

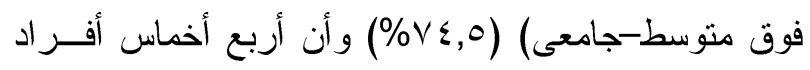

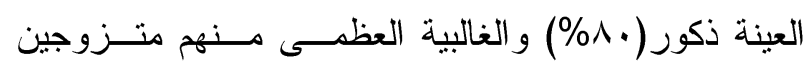

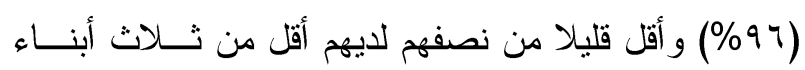

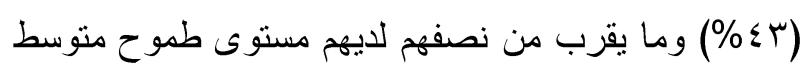

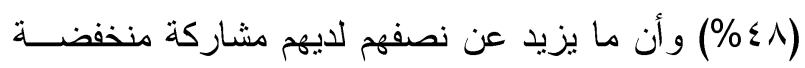

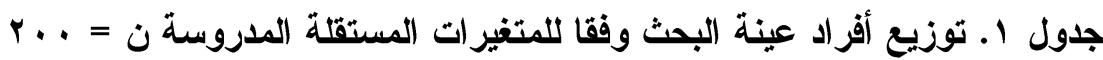

\begin{tabular}{|c|c|c|c|c|c|c|c|}
\hline$\%$ & عدد & الفئات & المتغير ات & $\%$ & عدد & الفئات & المتغير ات \\
\hline $0 V, 0$ & 110 & منخفض (أقل من • ( درجات) & المشاركة & $r 0,0$ & VI & صغير (أقل من ع كاسنة) & \\
\hline ro & $v$. & متوسط( · 1-01) درجة & & $r q, 0$ & $\vee 9$ & متوسط (ع ب - عـنة) & صاحب \\
\hline V & 10 & مرتفع ( أكثر من 1 درجة) & المنظمات الرسمية & ro & 0. & كييز (أكثر من ^عسنة) & المشروع \\
\hline$\wedge$ & IV & منخفض أقل من (ז ادرجة) & المشاركة & $\Lambda, 0$ & IV & (1) & المستوى \\
\hline or,o & $1 \cdot v$ & متوسط (ب ا-ـ ادرجة) & الاجتماعية & 11 & rt & يقراً ويكتت & التعليمى \\
\hline$r v, 0$ & VV & مرتفع(أكثر من V درجة) & غير الرسمية & 7 & ir & أُقل من المتوسط (9- ד) & لصآحب \\
\hline r & $\varepsilon$ & منخفض (أقل من ₹ ادرجة) & مستوى الطموح & $\varepsilon \cdot, 0$ & $\wedge$ & مؤ هل متوسط & المشروع \\
\hline$\varepsilon \wedge$ & $r \leq$ & متوسط(ي أ - آدرجة) & & 1 . & r. & مؤهل فوق المتوسط (ع ()) & \\
\hline$\wedge y$ & IVY & مرتفع (أكثر من r זدرجة) & & Y & $\varepsilon \wedge$ & مؤهل عالى (1 (1) & \\
\hline $1 \leq$ & rᄉ & منخفض (أقل من لدرجات) & الانفتاح الجغر افح & $\wedge$. & 17. & ذَكر & النوع \\
\hline VT & $1 \leqslant 4$ & متوسط( '^-r ادرجة) & & $r$. & $\varepsilon$. & أنثخ & \\
\hline 1r & ry & مرتفع (أكثر من ب ادرجة) & & & & & \\
\hline \multirow{6}{*}{$\begin{array}{c}r q \\
00,0 \\
0,0\end{array}$} & $v \wedge$ & منخفض( أقل من ا ادرجة) & الانفتاح & 97 & 194 & & 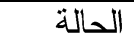 \\
\hline & 111 & متوسط(1) 1-V ادرجة) & النقافى & $\varepsilon$ & $\wedge$ & مطلق (أرمل) & الزوجية \\
\hline & 11 & مرتفع (أكثر من VI درجة) & & & & & \\
\hline & & & & $\leqslant 7$ & 95 & صغير أقل من (r) & 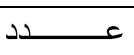 \\
\hline & & & & $\varepsilon r$ & $\wedge 7$ & متوسط (ب-0 (-0) & 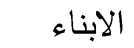 \\
\hline & & & & 11 & YY & كبير ( ه فأكثر) & \\
\hline
\end{tabular}


جدول r. توزيع عينة البحث وفقا لأثر المشروعات الصغيرة في الجاتب الاقتصادي لأسرهم

\begin{tabular}{|c|c|c|}
\hline$\%$ & عدد & الفئات \\
\hline $1 \varepsilon, r$ & rq & 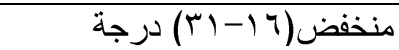 \\
\hline זT & Ir4 & 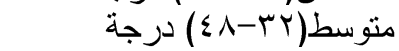 \\
\hline rY,O & «o & مرتفع(9 §- ؟ ؟) درجة \\
\hline $1 \ldots$ & r... & المجموع ع \\
\hline
\end{tabular}

جدول ب. توزيع عينة البحث وفقا لمستوى تحسين الاخل لأسرهم

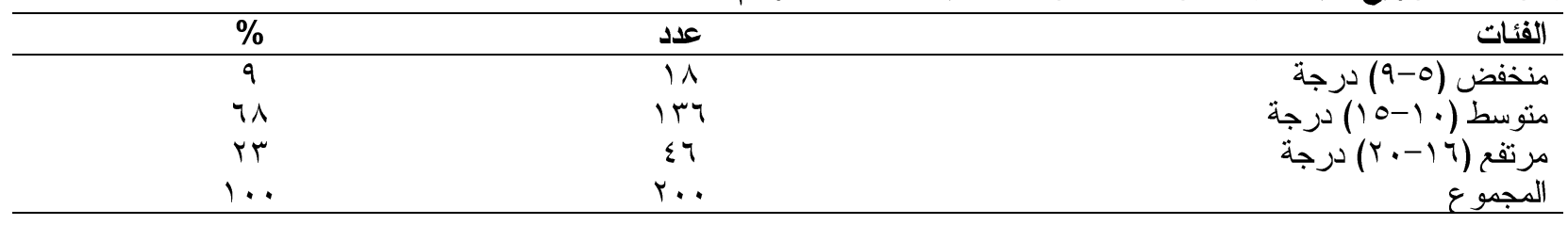

يعرض جدول(ه) توزيع عينة البحث وفقا لتحسين انفاق

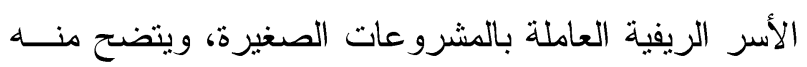

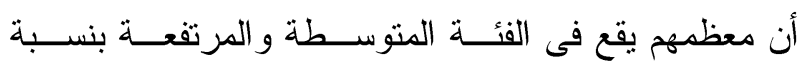

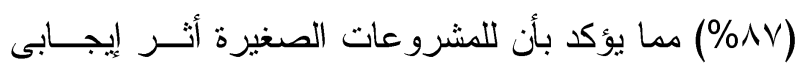
وفعال فى تحسين انفاق تلك الأسر. كما يعرض جدول(7) توزيع عينة البحث وفقـــا لأثـر

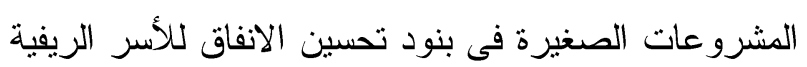

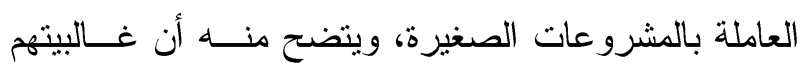

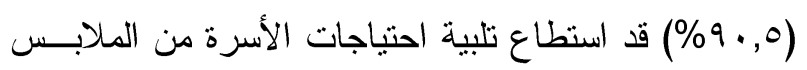

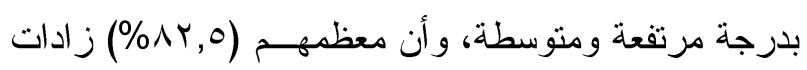

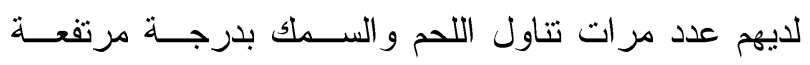

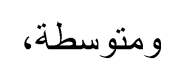

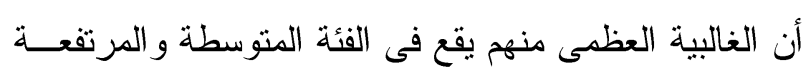

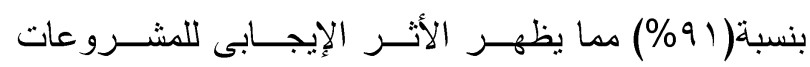
الصغيرة فى تحسين الدخل لتلك الأسر . الأبح

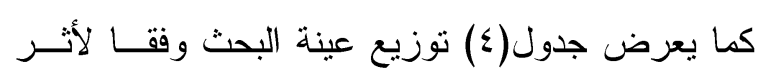
المشروعات فى بنود تحسين دخل الأسر الريفيــة العاملـــة

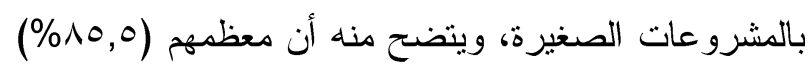

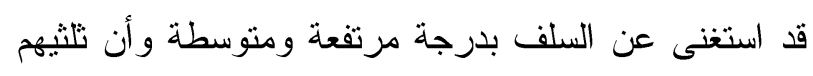

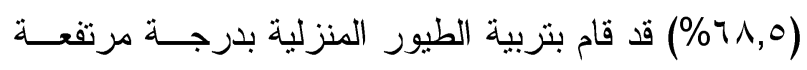

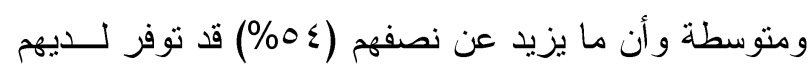

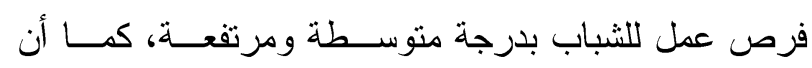
غالبيتهم (1/^V) قد تمكن من سداد الديون الأسرية.

$$
\text { ب- تحسين الانفاق: }
$$

\begin{tabular}{|c|c|c|c|c|c|c|c|c|}
\hline \multicolumn{2}{|c|}{$\gamma$} & \multicolumn{2}{|c|}{ بارجة منخفضة } & \multicolumn{2}{|c|}{ بلبرجة متوسطة } & \multicolumn{2}{|c|}{ بل بلرجة مرتفعة } & \multirow{2}{*}{ الاستجابات } \\
\hline$\%$ & عدد & $\%$ & عدد & $\%$ & عدد & $\%$ & عدد & \\
\hline 7 & IT & $\lambda, 0$ & IV & $r \uparrow, 0$ & or & 09 & 111 & 1- الاستغناء عن السلف \\
\hline ir & r4 & 11,0 & rv & $r, 0$ & זיד & rv & $v \varepsilon$ & ז-تربية الطيور المنزلية \\
\hline rV & $0 \leqslant$ & 19 & ru & $r T, O$ & 10 & $r, 0$ & $\varepsilon r$ & س-توفير فرص عمل للثشباب \\
\hline صفر & صفر & $1 \pi$ & rq & 74 & Tr & r & $\varepsilon r$ & ع - سداد ديون الأسرة \\
\hline 70 & $1 \pi$. & 11 & r4 & ir & $r \leq$ & 0 & 1. & ه- تحسين الانتاج الزر اء \\
\hline
\end{tabular}

جدول ع. توزيع عينة البحث وفقا لأثر المشروعات الصغيرة فى بنود تحسين دخل الأسر الريفية

\begin{tabular}{|c|c|c|}
\hline$\%$ & عدد & الفئكــــات \\
\hline$\pi$ & rq & منخفض (؟-1 () درجة \\
\hline $0 \leqslant, 0$ & 1.9 & متوسط (r (1-1 ) درجة \\
\hline$\mu_{Y, O}$ & 70 & مرتفع (9ُ 1-乏 r) درجة \\
\hline $1 \ldots$ & r.. & المجموع ع الت \\
\hline
\end{tabular}

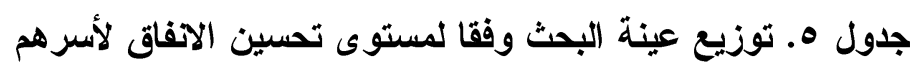


جدول 4.

\begin{tabular}{|c|c|c|c|c|c|c|c|c|}
\hline \multicolumn{2}{|c|}{$\gamma$} & \multicolumn{2}{|c|}{ بلدرجة منخفضة } & \multicolumn{2}{|c|}{ بلرجة متوسطة } & \multicolumn{2}{|c|}{ بلرجة مرتفعة } & \multirow[t]{2}{*}{ الاستجابات } \\
\hline$\%$ & عدد & $\%$ & عدد & $\%$ & عدد & $\%$ & عدد & \\
\hline$\varepsilon$ & $\wedge$ & 0,0 & 11 & rA & 07 & $T r, 0$ & iro & 1- تلبية احتياجات الأسرة من الملابس \\
\hline 0,0 & 11 & ir & r & 01,0 & $1 . \mu$ & M & Tr & ץ- -زيادة عدد مر ات تتاول اللحم و السمك \\
\hline 11,0 & r & 11,0 & rV & rq & $\vee \wedge$ & r & Tr & r- تحسين حالة بناء المسكن \\
\hline 19 & r人 & $r \uparrow, 0$ & or & rv & $v \varepsilon$ & $I V, 0$ & ro & عـ -تجديد أَثَاث المنزل \\
\hline$r \cdot, 0$ & $\varepsilon 1$ & $r \wedge, 0$ & ov & $r \varepsilon$ & 71 & iv & $\Gamma \varepsilon$ & 0- شر اء الأجهزة المنزلية الحديثة \\
\hline or & $1 \cdot \varepsilon$ & Yo,0 & 01 & $1 V, 0$ & ro & 0 & 1. & ؟- شر اء الكماليات (سيارة - ذهب) \\
\hline
\end{tabular}

ب- أثر المشروعات الصغيرة على الجانــب الاجتمــــ

\section{لنأسر الريفية:}

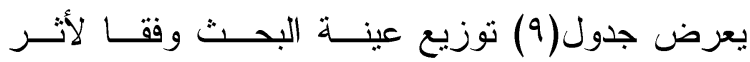

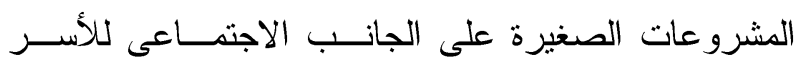

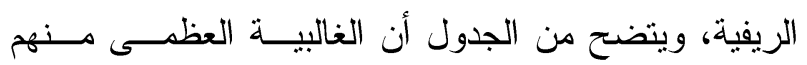
(\%9V) المشروعات الصغيرة فى تحسين الجانب الاجتماعى للأسر

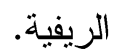

وباستعر اض النتــائج البحثبــة للأبعــاد الــثلاث للجانـبـ الاجتماعى اتضع مايلى:

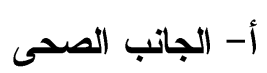
يعرض جدول(· () توزيع عينة البحث وفقــا لتحسـين المستوى الصحى للأسر الريفيــة العاملــة بالمشــروعات الصغيرة، ويتضح منه أن الغالبية العظمى منهم يقع فى الفئة

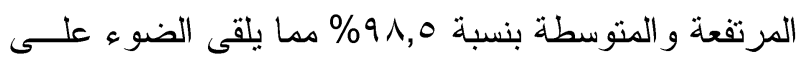
أن للمشروعات الصغيرة أثر إيجابى وفعال فـى تحسـئهين المستوى الصحى للأسر العاملة بتلك المشرو عات. كما يعرض جدول(1) (1) توزيع عينة البحث وفقا لأثــر المشروعات الصغيرة فى بنود تحسين المستوى الصــحى،

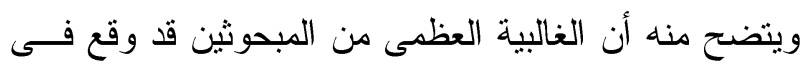
الفئة المرتفعة و المتوسطة لبنود: البعد عن اســتخدام ميــاه

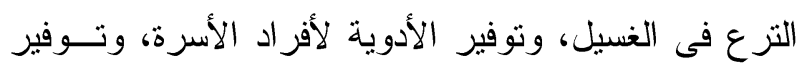

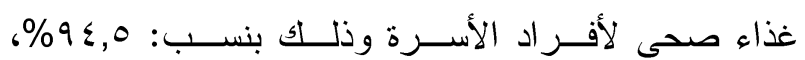

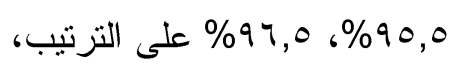

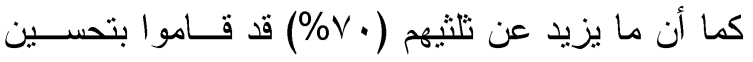

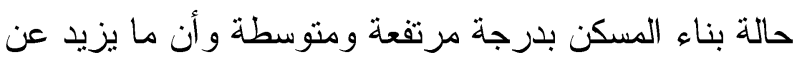

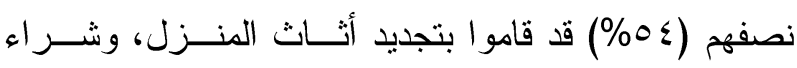
الأجهزة المنزلية الحديثة بدرجة مرتفعة ومتوسطة. ج- تنمية القدرة على الادخار: يعرض جدول(V) توزيع عينة البحث وفقا لتمية القدرة على الادخار لأسر العاملين بالمشروعات الصغيرة، ويتضح

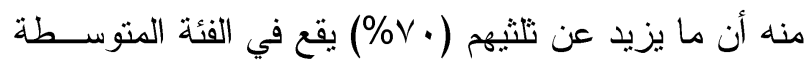
و المرتفعة، مما يشير إلى أن للمشروعات الصـــيرة أثــر

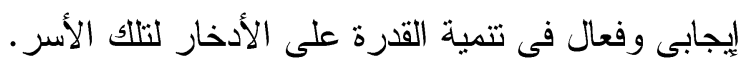
جدول V. توزيع عينة البحث وفقا لمستوى تنمية القـــرة

\begin{tabular}{|c|c|c|}
\hline$\%$ & عدد & الفئـــــــــات \\
\hline r. & 7. & منخفض (0-9) درجة \\
\hline os & $1 \cdot 1$ & متوسط (· (10 1) درجة \\
\hline 17 & Tr & مرتفع († ا - ץ) درجة \\
\hline $1 \ldots$ & r... & المجمو ع \\
\hline
\end{tabular}

كما يعرض جدول(^) توزيع عينة البحث وفقــا لأثــر المشروعات الصغيرة فى بنود تتمية القدرة على الأدخــار

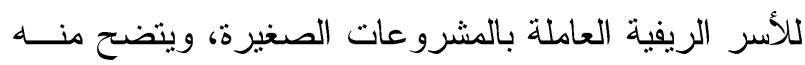

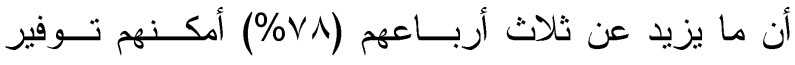
متطلبات زواج الأبناء بدرجة مرتفعة ومتوسطة، وأن ثلثيهم

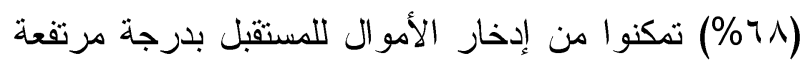

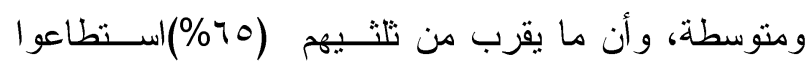

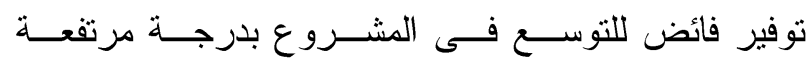
ومتوسطة. 
جدول ^. توزيع عينة البحث وفقا لأثر المشروعات الصغيرة فى بنود تحسين تنمية القدرة على الإدخار لأسرهم

\begin{tabular}{|c|c|c|c|c|c|c|c|c|}
\hline \multicolumn{2}{|c|}{$\gamma$} & \multicolumn{2}{|c|}{ بلرجة منخفضة } & \multicolumn{2}{|c|}{ بلرجة متوسطة } & \multicolumn{2}{|c|}{ بلدرجة مرتفعة } & \multirow[t]{2}{*}{ الاستجابات } \\
\hline$\%$ & عدد & $\%$ & عدد & $\%$ & عدد & $\%$ & عدد & \\
\hline 9 & 11 & 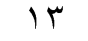 & YY & $r \uparrow, 0$ & or & 01,0 & $1 . r$ & 1-توفير متطلبات زو اج الأبناء \\
\hline $1 Y, 0$ & ro & 19,0 & rq & rV & $v \varepsilon$ & T & Tr & ץ- إدخار بعض الأمو ال للمستقبل \\
\hline 10 & r. & $r$. & $\varepsilon$. & rv & $V \varepsilon$ & rᄉ & $0 y$ & r- تُوفير فائض للتوسع فى المشرو ع \\
\hline $0 V, 0$ & 110 & r) 1,0 & $\varepsilon r$ & 10,0 & ו & 0,0 & 11 & ش \\
\hline$\rceil \varepsilon$ & I ra & iv & $\mu \varepsilon$ & 10,0 & r & $r, 0$ & $\mathrm{v}$ & 0- شر اء حبو انات مزر عية \\
\hline
\end{tabular}

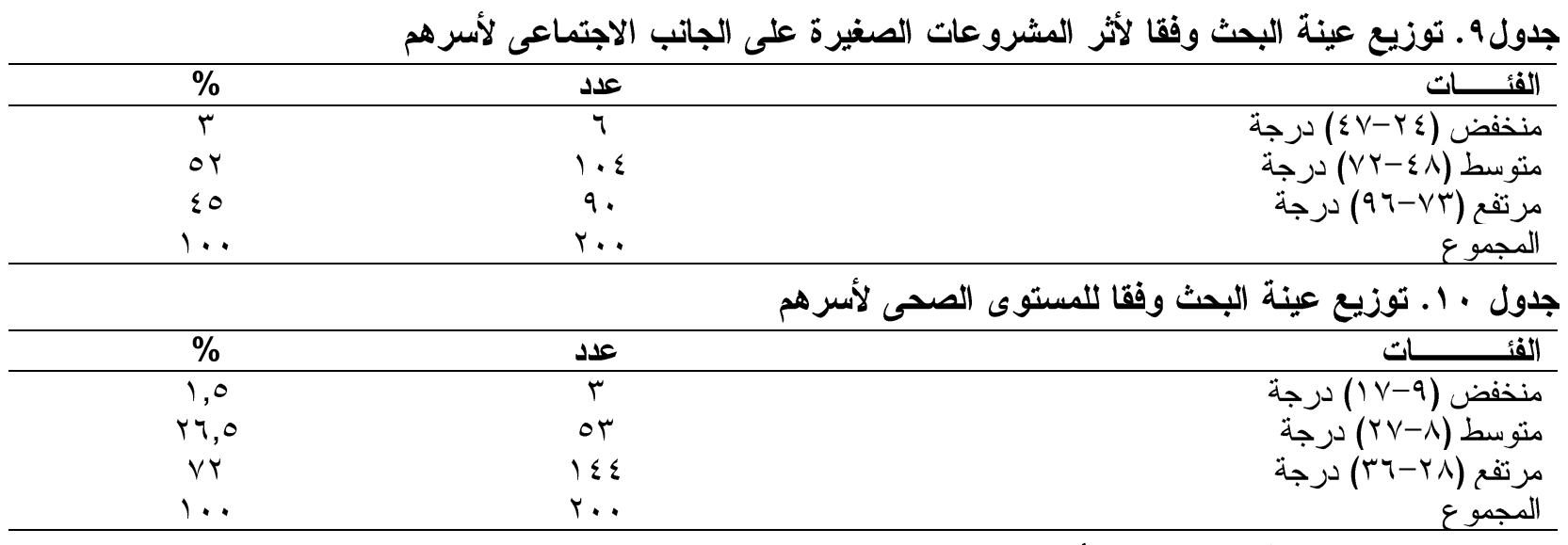

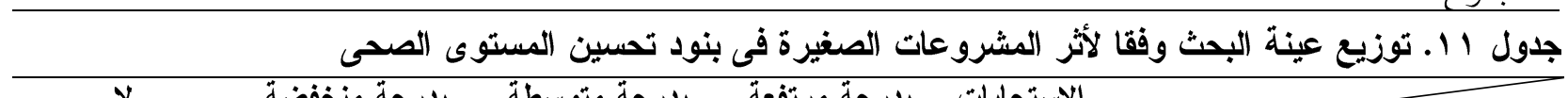

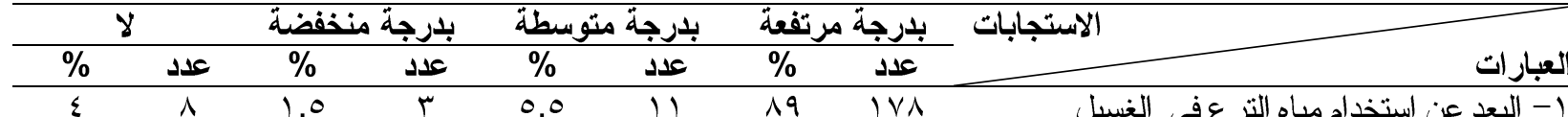

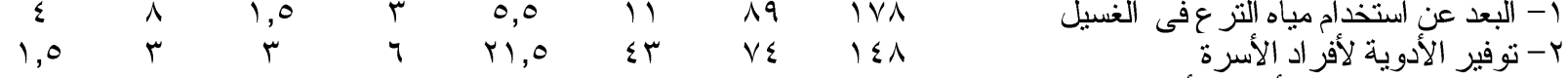
r-

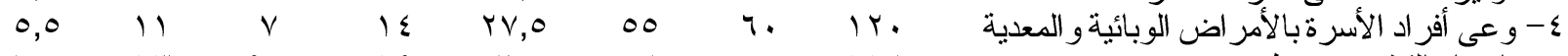

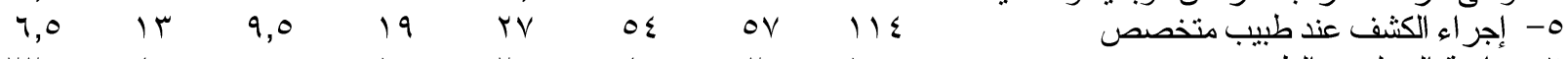

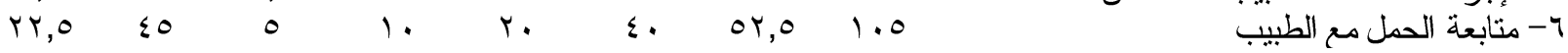

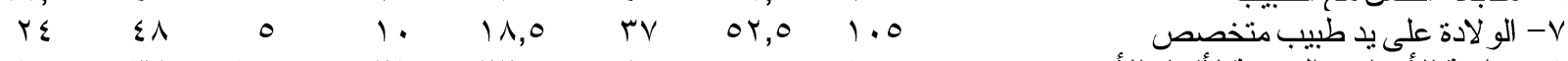
IV

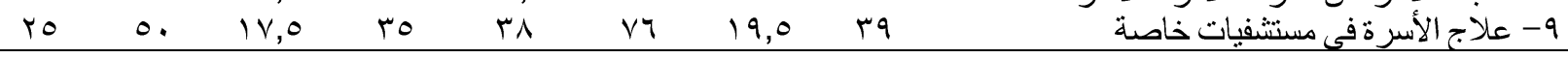

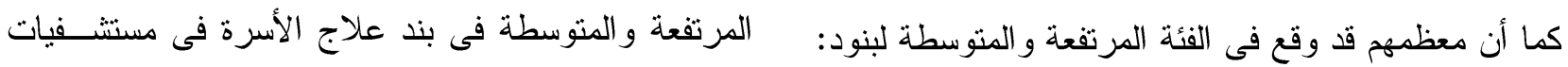

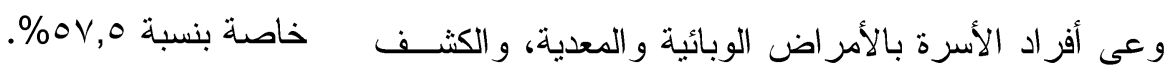

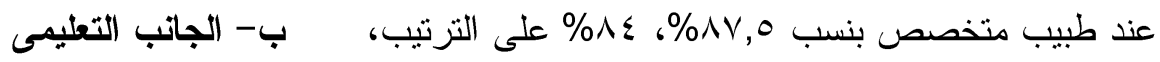
يعرض جدول(Y I) توزيع عينة البحــث وفقـــا لأثــر المشروعات الصغيرة فى تحسين الجانب التعليمى للأسـر وأن ما يقرب من ثلاث أرباعهم قد وقع فى الفئة المرتفعـة بـابة

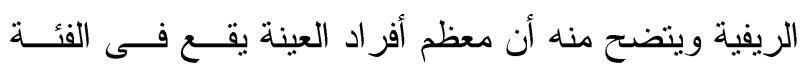
و المتوسطة لبنود: متابعة الحمل مع الطبيب، و الولادة على يد طبيب متخصص، ومتابعة الأمر اض المزمنــة لأفـــراد

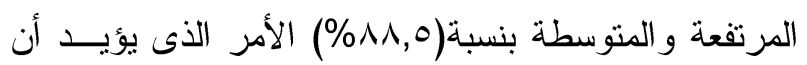

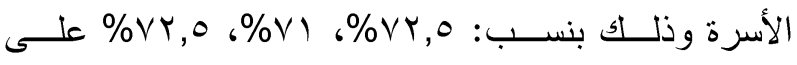
المشروعات الصغيرة تؤثر بشكل فعال فى تحسين المستوى الترتيب، أما ما يزيد عن نصف المبحوثين قد وقع فى الفئة التعليمى للأسر العاملة بتلك المشروعات. 
الأثز الواضتح للمشروعات الصغيرة فــى رفــع المكانــة الاجتماعية للأسر العاملة بالمشروعات الصغيرة. كما يعرض جدول(0) 10 توزيع عينة البحث وفقا لأثــر المشروعات الصغيرة فى بنود تحسين المكانة الاجتماعيــة،

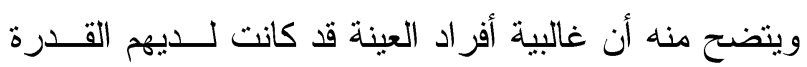

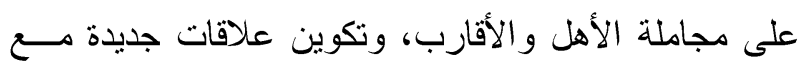

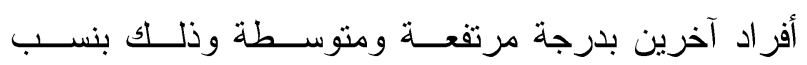
90,0\%، 19 \% على الترتيب، كما أن معظمهم قام بتطبيق

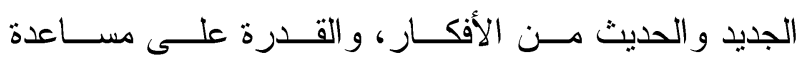
المحتاجين فى القرية بدرجة مرتفعة ومتوسطة، وذلك بنسب

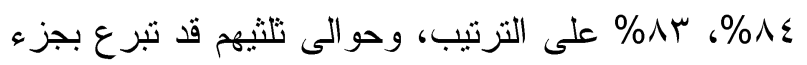

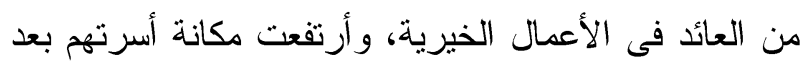

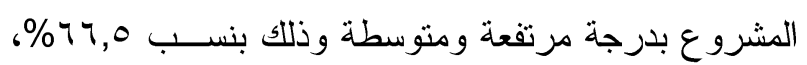

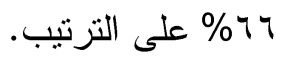
مما سبق يتضح أن المشروعات الصـــغيرة لهــــا أثــر

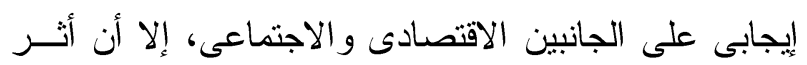
تللك المشروعات أكثر وضوحا فى الجانب الاجنماعى بنسبة

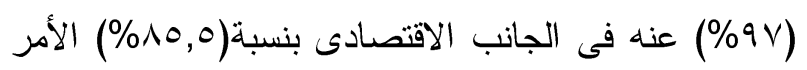

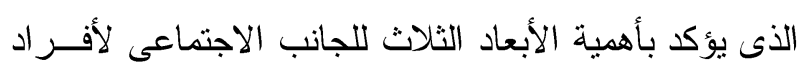

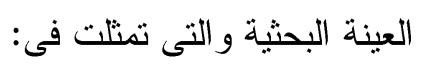

جدول r ا ـ توزيع عينة البحث وفقا لتحسـين المسـتوى

\begin{tabular}{|c|c|c|}
\hline & & التعليمى لأسرهم \\
\hline$\%$ & عدد & الفئــــــــــات \\
\hline 11,0 & $r$. & منخفض (ر-0 (1) درجة \\
\hline$T Y, O$ & iro & منوسط (T 1- ك) درجة \\
\hline ry & or & 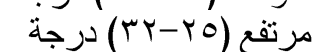 \\
\hline $1 \ldots$ & r... & المجموع ع الم \\
\hline
\end{tabular}

كما يعرض جدول (س (1) توزيع عينة البحث وفقا لأثـر

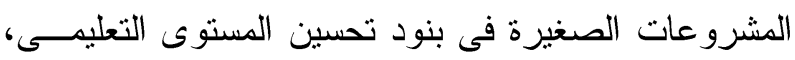

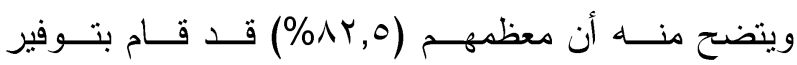

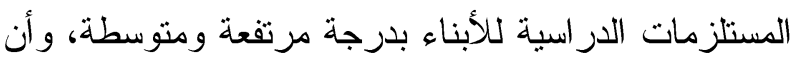
تلثيهم (\%TV,0) قد انشترى الكمبيوتز لمساعدة الأبناء علي

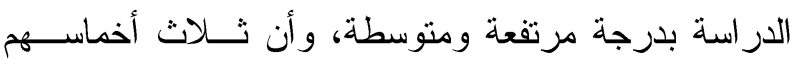

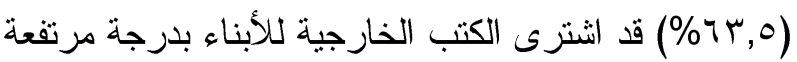
ومتوسطة، وأن نصفهم ( (\%) قد حصـل علـى دورات تدريبية خاصة (كمبيوتز - لغات) بدرجة مرتفعة ومتوسطة.

ج- جانب المكانة الاجتماعية يعرض جدول(ك () توزيع عينة البحـــث وفقــا لأثــر المشروعات الصغيرة فى تحسين جانب المكانة الاجتماعية للأسر الريفية، ويتضح منه أن الغالبية العظمى لأفراد العينة يقع فى الفئة المرتفعة و المتوسطة بنسبة (ع 9\%) مما يعزز

\begin{tabular}{|c|c|c|c|c|c|c|c|c|}
\hline \multicolumn{2}{|c|}{$\bar{\gamma}$} & \multicolumn{2}{|c|}{ منخفضة } & \multicolumn{2}{|c|}{ بلرجة متوسطة } & \multicolumn{2}{|c|}{ بل برجة مرتفعة } & \multirow[t]{2}{*}{ الاستجابات } \\
\hline$\%$ & عدد & $\%$ & عدد & $\%$ & عدد & $\%$ & عدد & \\
\hline 17,0 & r & 1 & $r$ & 10 & $r$. & $T V, 0$ & 1ro & 1- توفير المستلزمات الدر اسية للأبناء \\
\hline$r ૫, 0$ & or & ч & ir & $1 \wedge$ & 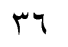 & $\leqslant 9,0$ & 99 & r- شر اء كمبيوتز لمساعدة الأبناء فى الدر اسة \\
\hline iv & $0 \leqslant$ & 9 & 11 & r & $\varepsilon V$ & $\varepsilon \cdot, 0$ & $\wedge$ & ب- شر اء كتب خار جية للأبناء \\
\hline$T \leq$ & 71 & 17 & Tr & tV & $0 \leq$ & Tr & $\leqslant 7$ & ع -الحصول على دور ات تدريبية خاصة (كمبيوتر - لغات) \\
\hline$\leqslant 0,0$ & 91 & 14,0 & rV & $r \cdot, 0$ & $\varepsilon 1$ & $r \cdot, 0$ & $\varepsilon 1$ & 0- توفير مدرس خصوصى لتعليم الأبناء \\
\hline$\sum r$ & $\wedge \varepsilon$ & 17 & rt & T纟 & $\varepsilon \wedge$ & $1 \wedge$ & ب & ؟- تكوين مكتبة بالمنزل للتثقيف \\
\hline N) & 174 & $\Lambda$ & 17 & 7,0 & ז & $\varepsilon, 0$ & 9 & V V إلتحاق الأبناء بالمدارس الخاصة - V \\
\hline 79 & 1 r & 9 & 11 & $1 \cdot, 0$ & r) & 11,0 & r & ^- ألتحاق الأبناء بالجامعات الخاصة \\
\hline
\end{tabular}

جدول \& 1. توزيع عينة البحث وفقاء لتحسين مستوى المكانة الاجتماعية لأسرهم

\begin{tabular}{|c|c|c|}
\hline$\%$ & عدد & الفئـــــــات \\
\hline 7 & Ir & منخفض (V-V r I) درجة \\
\hline$\varepsilon r$ & $\wedge \varepsilon$ & متو سط (ي ا - (Y) درجة \\
\hline or & $1 \cdot \varepsilon$ & مرتفع (YY-YA) درجة \\
\hline $1 \cdots$ & r... & المجمو ع ل \\
\hline
\end{tabular}




$$
\text { مجلة الإسكندرية للتبادل العلمى - (مجلدVT العدد ) أكتوبر - ديسمبر } 17 \text {. }
$$

جدول ه ا. توزيع عينة البحث وفقا لأثر المشروعات الصغيرة فى بنود تحسين المكانة الاجتماعية

\begin{tabular}{|c|c|c|c|c|c|c|c|c|}
\hline \multicolumn{2}{|c|}{$\gamma$} & \multicolumn{2}{|c|}{ بلرجة منخفضة } & \multicolumn{2}{|c|}{ بلرجة متوسطة } & \multicolumn{2}{|c|}{ بلارجة مرتفعة } & \multirow{2}{*}{ العبار ات } \\
\hline$\%$ & عدد & $\%$ & عدد & $\%$ & عدد & $\%$ & عدد & \\
\hline صفر & صفر & $\varepsilon, 0$ & 9 & 崩 & TY & $7 \leqslant, 0$ & 149 & ا - القدرة على مجاملة الأهل و الأقارب \\
\hline$r$ & 7 & 7 & ir & rV & $0 \leqslant$ & $\Upsilon \varepsilon$ & IrA & r- تكوين علاقات جديدة مع أفر اد آخرين \\
\hline 0,0 & 11 & $1 \cdot, 0$ & YI & $\varepsilon 1$ & Ar & $\varepsilon r$ & $\wedge 4$ & r- تطبيق الجديد و الحديث من الأفكار \\
\hline$\varepsilon, 0$ & 9 & $1, Y, 0$ & ro & $\varepsilon r$ & $\wedge \uparrow$ & $\varepsilon$. & $\Lambda$. & ع - القدرة على مساعدة المحتاجين \\
\hline 11,0 & Tr & r & $\varepsilon \varepsilon$ & r & $7 \uparrow$ & Tr,O & 70 & ه-التبر ع بجزء من العائد فى الأعمال الخيرية \\
\hline 17 & rt & 11 & 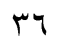 & ه & $\checkmark$. & ו & Tr & צ- ارتفاع مكانة الأسرة بعد المشرو ع \\
\hline or & 1.7 & 17,0 & س & Y),0 & $\varepsilon r$ & 9 & $1 \wedge$ & 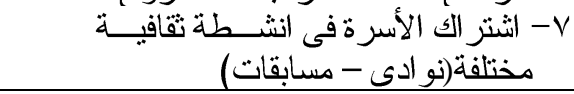 \\
\hline
\end{tabular}

الذى يلقى الضوء على أهمية المشروعات الصغيرة، وذلك

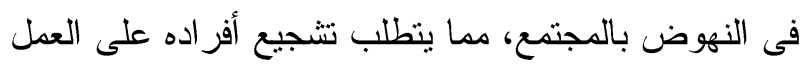

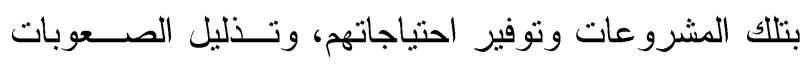
و العقبات التى تقف عثرة فى طريق نجاح هذه المشروعات،

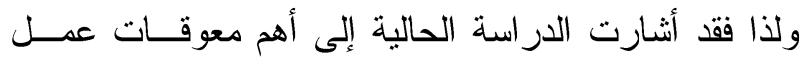

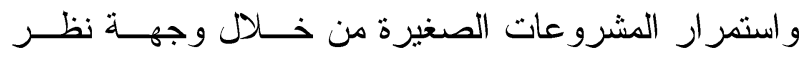
و آراء العاملين بها، لإمكانية اقتراح الحلول اللازمة للتغلب عليها.

ع - معوقات عمل واستمرار المشروعات الصغيرة: يتضح من جدول(T 1) أن اهم معوقات عمل واستمرار المشروعات الصغيرة وفقا لوجهات نظر آراء أفراد عينــة مادة

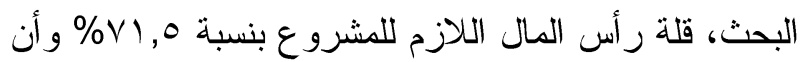
ما يزيد عن نصف أفراد العينة يرجعوا تلك المعوقات إلـىى مشكلات الضرائب و الرسوم و التأمينات وصـــوبة تـــوفير ومما سبق يتضح ان التمويل هو المشــكلة الأساســية

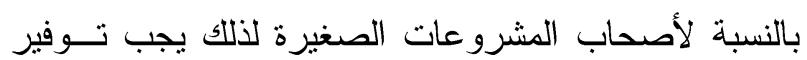
مصادر تمويل توفر الاستمرار الآمن لتلك المشروعات. الخدمات اللازمة للمشروع.

الجانب الصحى، و الجانـب التعليمــى، وجانــب المكانــة الاجتماعية، كما أن أبرز بنود تحسين الجانب الصحى هى: البعد عن استخدام مياه التزع فى الغسيل، وتوفير الأدويــة

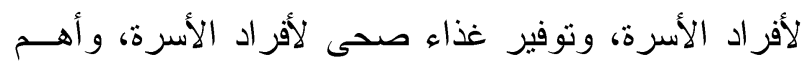

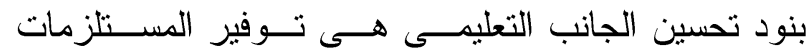

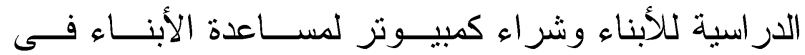
الدر اسة، وشر اء كتب خارجية للأبنــاء وبالنســبة لجانــبـ المكانة الاجتماعية فقد كانت بنود القدرة على مجاملة الأهل الأقارب، وتكوين علاقات جديدة مع أفراد آخرين، وتطبيق بلى

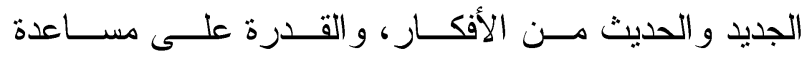
المحتاجين فى القرية ذات الأولوية لهم. وبناء على ذللك فإن نتائج تللك الدر اسة تؤيد بان زيــادة

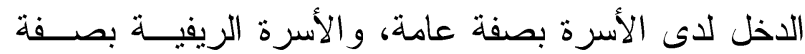
خاصة تتفق فى إثباع احتياجات أفر ادها للارتقاء بالجوانب الاجتماعية التى تأتى فى المرتبة الثانية بعد إثباع الحجات

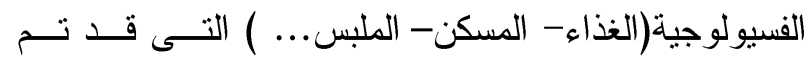

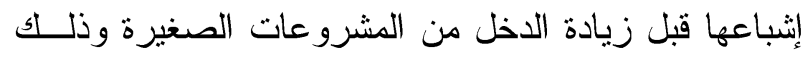
وفقاً لما ذكره "هرم ماسلو" للحاجات الإنسانية تبعا لدرجــة رهنة قوة إلحاح تلك الحاجات وتأثير ها على نوجيه السلوك، الأمر

جدول 17 ـ توزيع عينة البحث وفقا لمعوقات عمل واستمرار المشروعات الصغيرة

\begin{tabular}{|c|c|c|c|}
\hline الترتيب & $\%$ & 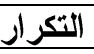 & العبــــــار ات \\
\hline الأول & $v 1,0$ & $1 \leqslant r$ & 1- قلة رأس المال اللازم للمشرو ع \\
\hline الثانى & $09, \cdots$ & 111 & r- مشكلة الضر ائب و الرسوم و التأمينات \\
\hline 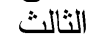 & or,o & 1.0 & r- صعوبة توفر الخامات اللازمة للمشرو ع \\
\hline 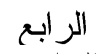 & 01, & $1 \cdot r$ & ع- ارتفاع أسعار الفائدة على القروض اللازمة للمشرو ع \\
\hline الخامس & $0 ., \cdots$ & $1 \ldots$ & 0- مشكلة استخر اج التز اخيص الخاصة بالمشرو ع \\
\hline
\end{tabular}


1- نتائج اختبار "ت" لاختبار الفروق بين المبحوثين فـى أثر المشروعات الصغيرة على الجوانسب الاقتصــادية التئية و الاجتماعية للأسر الريفية عند تصنيفهم تبعا لكل مسن التهن

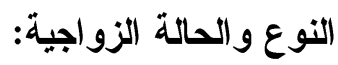
يوضح جدول (1/) نتائج اختبــار "ت" للفــروق بــين

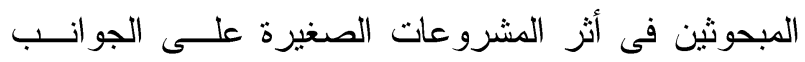

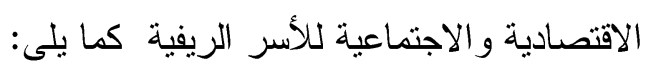

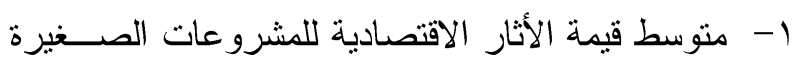

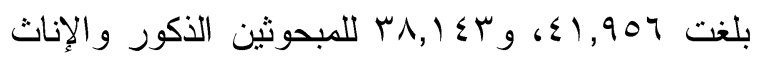
على التزتيب، وبلغت قيمــة "ت" المحســوبة لاختبـــــار

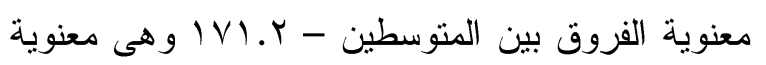

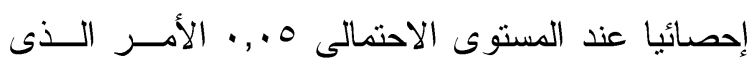

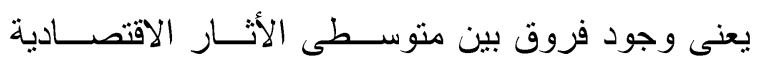

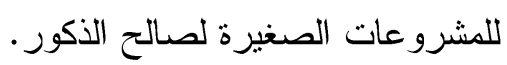

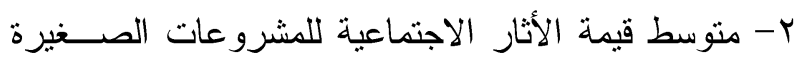

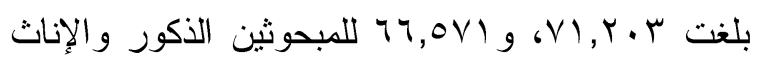

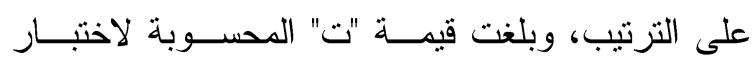

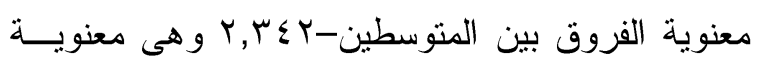

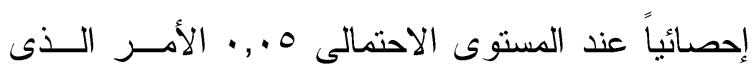

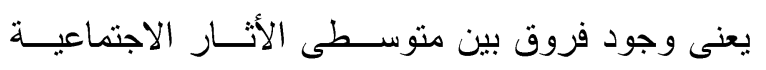

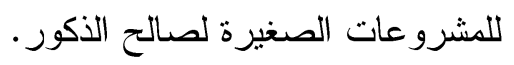

ه- العلاقات الارتباطية بين المتغيرات المستقلة المدروسة وأثر المشروعات الصغيرة على الجواتب الاقتصــادية و الاجتماعية للأسر الريفية:

باستعر اض نتائج معاملات الارتباط البسيط (بيرســـون)

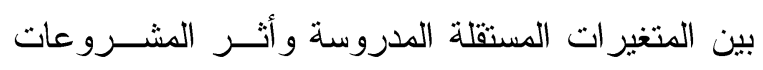

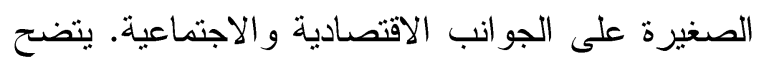

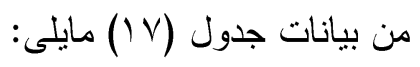

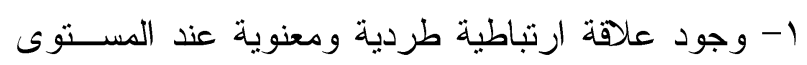
الاحتمالى 0 . . ببين المستوى التعليمى وكل من الجانبين

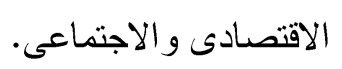

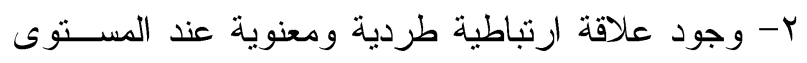

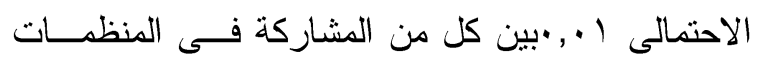

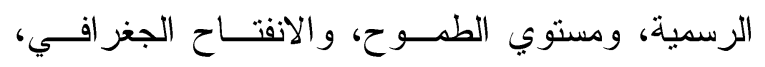

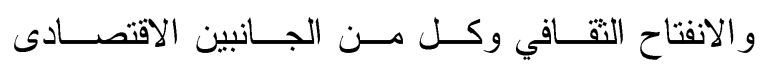

$$
\text { و الاجتماعى. }
$$

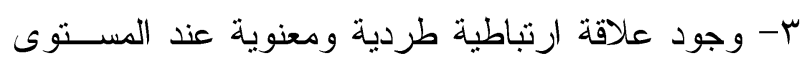

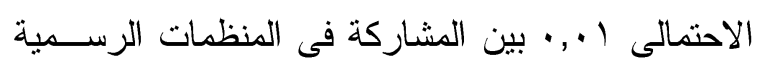

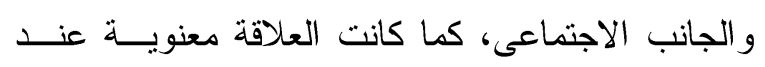

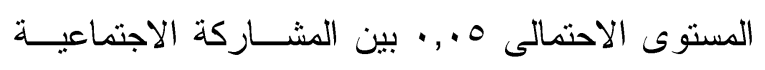

$$
\text { غير الرسمية و الجانب الاقتصادى. }
$$

\begin{tabular}{|c|c|c|}
\hline دور المشروعات في الجانب الاجتماعي & دور المشروعات في الجاتب الاثتصادى & التابع \\
\hline قيم معاملات الارتباط البسيط (بيرسون) & قيم معاملات الارتباط البسيط (بيرسون) & المستقل \\
\hline$\cdot, .0 r$ & $\cdot, \cdot \wedge r$ & السن \\
\hline$*, 170$ & $*, 1 \vee 0$ & المستوى الا \\
\hline.,.$r$. & $\cdot, \cdot \leq \wedge$ & عدد لأبناء \\
\hline$* *, r \wedge 1$ & $* *, Y Y$ & المشاركة فى المنظمات الرسمية \\
\hline$* *$, r & $*, 1 \vee 0$ & المشاركة الاجتماعية غير الرسمية \\
\hline$* *, \varepsilon \curlyvee q$ & $* *, r \leq \Lambda$ & مستوى الطمو ح \\
\hline$* *, \leqslant \circ \mathrm{V}$ & $* *, \Gamma \wedge \varepsilon$ & الانفتاح الجغر افى \\
\hline$* *, r q$ & $* *, Y \wedge \varepsilon$ & الانفتاح الثقاف \\
\hline
\end{tabular}

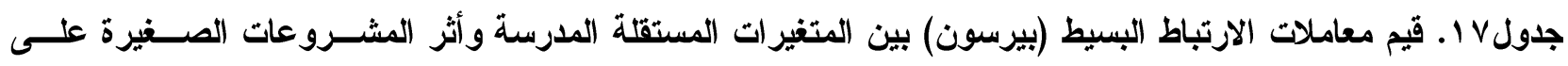
الجوانب الاقتصادية والاجتماعية علي الأسر الريفية 
مجلة الإسكندرية للتبادل العلمى - (مجلد Vr العددء) أكتوبر - ديسمبر 17

جدول ^1. نتائج إختبار "ت" لإختبار الفروق بين المبحوثين فيما يتعلق بـائثر المشــروعات الصــغيرو عـــى الجوانـب الإقتصادية والإجتماعية عند تصنيفهن على أساس النوع والحالة الزواجية

\begin{tabular}{|c|c|c|c|c|c|c|}
\hline \multirow{3}{*}{ "تيمة } & \multicolumn{4}{|c|}{ النوع } & \multirow[t]{3}{*}{ المتفير المستقل } & \multirow[b]{3}{*}{ الجوانب } \\
\hline & \multicolumn{2}{|c|}{ أنتخي } & \multicolumn{2}{|c|}{ زكر } & & \\
\hline & $\varepsilon$ & م & $\varepsilon$ & 5 & & \\
\hline$* Y,|\vee|-$ & 1,00 & $r \wedge, 1 \leqslant r$ & $\wedge, Y 91$ & $\{1,907$ & \multirow{7}{*}{ المتغير المستقل } & الجانب الإقتصادز \\
\hline$* r, r \leqslant Y-$ & $11, \varepsilon \cdot r$ & $74,0 \times 1$ & (1, & $V M, Y \cdot r$ & & الجانب الأجتماء \\
\hline \multirow{3}{*}{ قتيمة } & \multicolumn{4}{|c|}{ الحالة الزواجية } & & \\
\hline & \multicolumn{2}{|c|}{ مطلق( أرمل) } & \multicolumn{2}{|c|}{ متزوج } & & \\
\hline & $\varepsilon$ & م & $\varepsilon$ & م & & الجواتب \\
\hline$\cdot, \wedge \cdot Y-$ & $9,0 V V$ & $r \Lambda, 0$. & $\Lambda, q \cdot r$ & \&1,Yฯ4 & & الجانب الإقتصاد: \\
\hline *Y,YYו- & $7,+91$ & $70, \ldots$ & $11,7 \cdot 1$ & $V \cdot, \leqslant \leqslant 0$ & & الجانب الغجتماء \\
\hline
\end{tabular}

الرسمية، ومستوى الطموح و الإنتفاح الجغرافــى، و الإنتفــاح الثقافى مجتمعة نزتبط بأثز المشروعات الصغيرة على الجانب

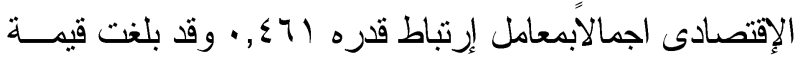

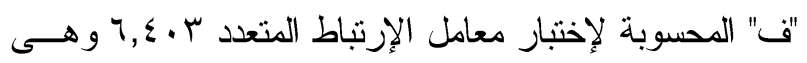

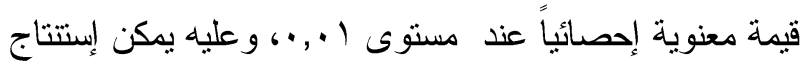
وجود علاقة إرتباطية متعددة بين المتغيرات المستقلة مجتمعسـة وبين الأثار الإقتصادية للمشروعات الصـــغيرة علــي الأســر

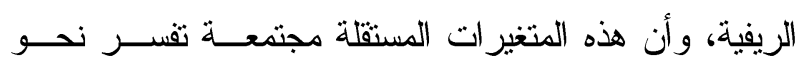

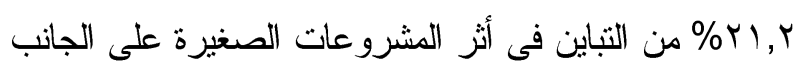
الإقتصادى، كما تبين بيانات نفـس الجــدول أن المتغيـرات

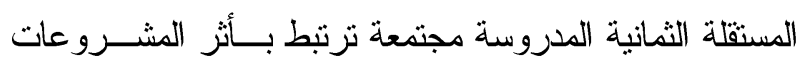

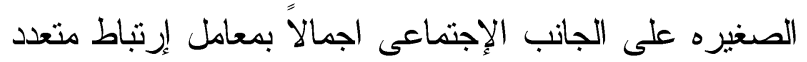

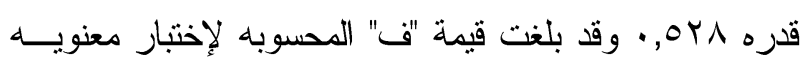
معامل الأرتباط المتعدد س7 ا,9 وهى قيمه معنويه إحصائياً عند

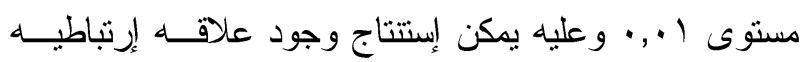

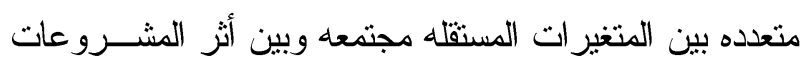
الصغيرة على الجانب الاجتماعى، وأن هذه المتغيرات المستقله

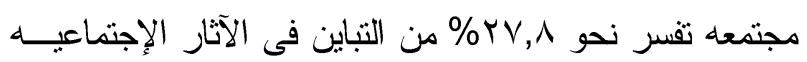
لمشرو عات الصغيره.

كما توضتح بيانات نفس الجدول نتائج النمـــوذج المختـزل

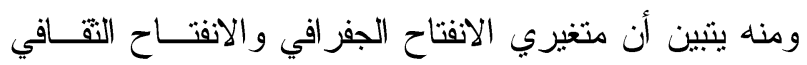

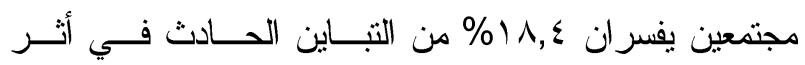
المشروعات الصغيرة علي الجوانب الاقتصادية للأسر الريفية
ب- متوسط قيمة الأثار الاقتصادية للمشروعات الصــغيرة

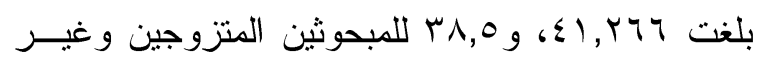

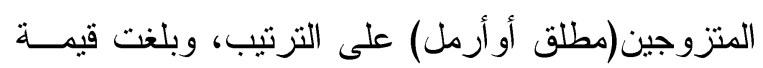
"ت" المحسوبة لاختبار معنوية الفروق بين المتوسطين-

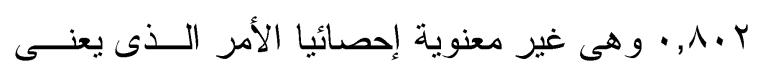

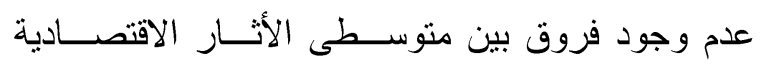

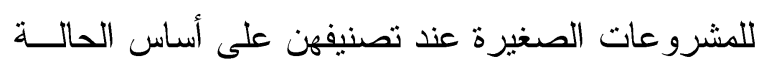

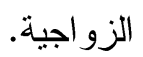
ـ- متوسط قيمة الأثار الاجتماعية للمشروعات الصـــغيرة

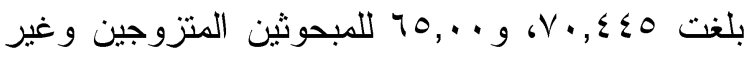
المتزوجين (مطلق أو أرمل) على الترتيب، وبلغت قيمة "ت" المحسوبة لاختبار معنوية الفروق بين المتوسطين-

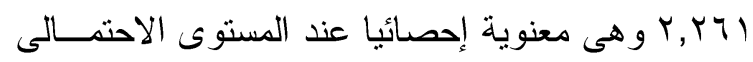

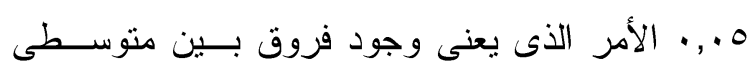

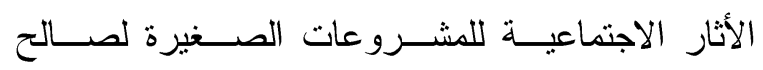

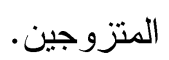

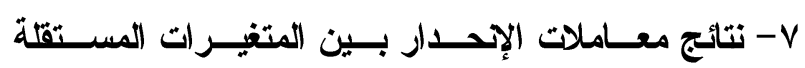

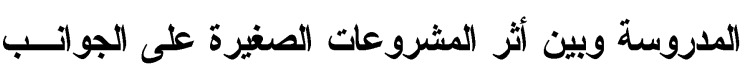
الإقتصادية والإجتماعية علي الأسر الريفية. توضح نتائج الإنحدار الخطى المتعدد المعروضة بجــدول

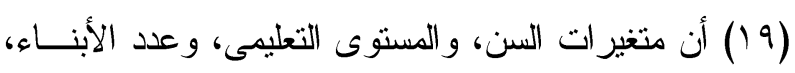
و المشاركة فى المنظمات الرسمية، و المشاركة الإجتماعية غير 
جدول 9 ا. العلاقات الإحدارية بين المتغيرات المستقةة المدروسة وأثر المشــروعات الصــيرة علـى الجوانـب الإقتصـادية والإجتماعية للأسر الريفية

\begin{tabular}{|c|c|c|c|c|}
\hline \multicolumn{2}{|c|}{ دور المشروعات في الجانب الاجتماعى } & \multicolumn{2}{|c|}{ دور المشروعات في الجانب الاقتصادى } & \multirow[t]{2}{*}{ التابع } \\
\hline (الجزئي المعياري) & (النموذج الاكامل) & (الجزئي المعياري) & (النموذج الاكامل) & \\
\hline \multirow[t]{3}{*}{$*,, 1 \leqslant \varepsilon$} & $\cdot, 100$ & &., $1 \cdot 1$ & 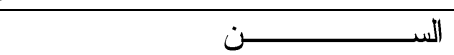 \\
\hline & אח .,. & & $\cdot, \cdot r_{1}$ & 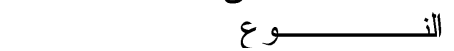 \\
\hline & $\cdot, \ldots r$ & & $\cdot, \cdot$ YOO- & الحالة الزو اجية \\
\hline \multirow[t]{4}{*}{$* *, r \backslash \Lambda$} & 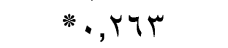 & & $\cdot, \cdot V-$ & المستوى التعليمى \\
\hline & $\cdot, \cdot, \varepsilon r_{-}$ & & $\cdot, \cdot 11-$ & عدد الأبناء \\
\hline & $\cdot, .11$ & & $\cdot, 111$ & المشاركة فى المنظمات الرسمية \\
\hline & 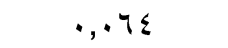 & & $\cdot, \cdot 1 \mathrm{~V}$ & المشاركة فى المنظمات غير الرسمية \\
\hline \multirow[t]{2}{*}{$* *, \varepsilon r r$} & $* *, 419$ & &., $1 \cdot 7$ & مستوى الطمو ح \\
\hline &., $.0 Y$ & $* *, \Gamma \wedge \varepsilon$ & $* *, r \cdot \varepsilon$ & الإنتقاح الجغر افى \\
\hline$* *, Y Y \Lambda$ & $*, 17 \varepsilon$ & $*, 19 \mathrm{~V}$ & $\cdot, \cdot \wedge \wedge$ & الأنفتاح النقافى \\
\hline .,OVT &., $0 \wedge$. & $\cdot, \leqslant Y q$ & $\cdot, \leqslant 71$ & $\mathrm{R}$ \\
\hline 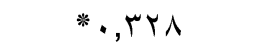 & $r v, v$ & $\cdot, 1 \wedge \varepsilon$ & r), & $\mathrm{R}^{2}$ \\
\hline **ฯ, ฯฯ. & $* \because, 0 \leqslant 0$ & $* * Y, \cdot \Delta r$ & $* 0, \cdot 10$ & $\mathrm{~F}$ \\
\hline
\end{tabular}

ب-نوفير الفرص أمام الأسر الريفيه للإتصــال بـالمراكز

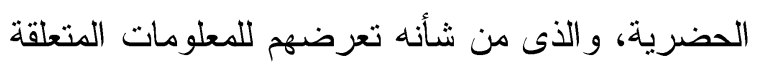

$$
\text { بالمشور عات الصغيرة. }
$$

ع-در اسة المشكلات و العقبات التى تقف في سـبيل نجــــاح المشروعات الصغيرة وإيجاد الحلول لها لتشجيع الأسر

$$
\text { الريفية على العمل بها و إستمر ارها. }
$$

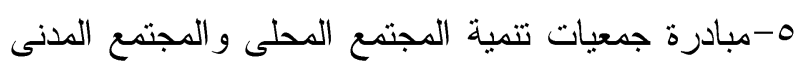

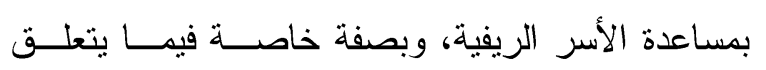

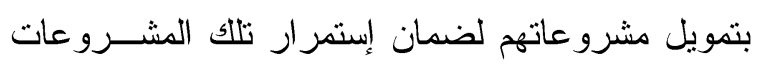

$$
\begin{aligned}
& \text { وتحقيق الأمان لتلك الأسر - بنتروع }
\end{aligned}
$$

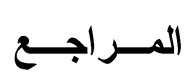

إبر اهيم، عماد محمد عبــد القـادر ع ـ . ب: الآثــار الإجتماعيــة والإقتصادية لبعض المشروعات التى يمولها صندوف التنمية

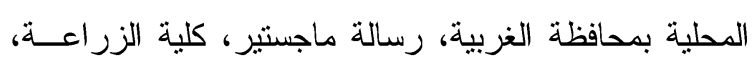

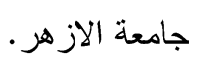

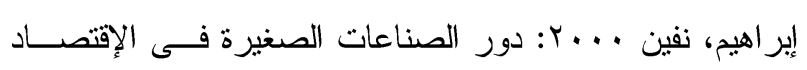

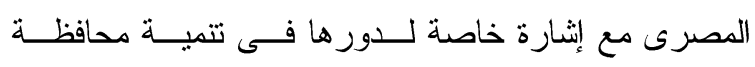
المنوفية، رسالة ماجستير ، كلية التجارة، جامعة المنوفية.
وأن متغير الانفتاح الجغرافي هي الأقوي تأثيراً يليه الانفتــاح

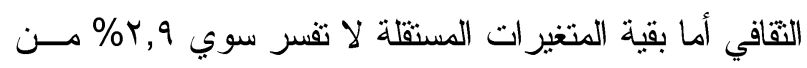

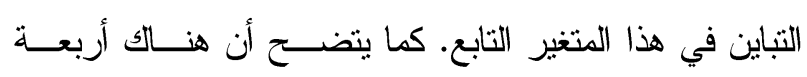

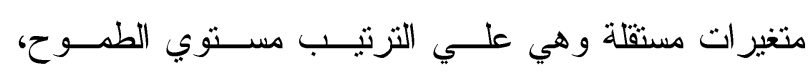

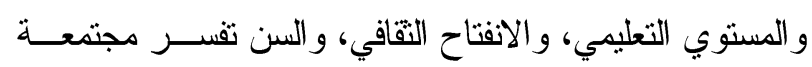

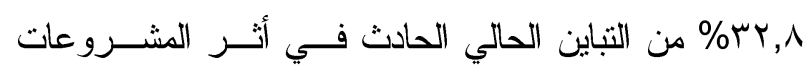

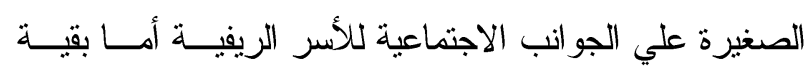

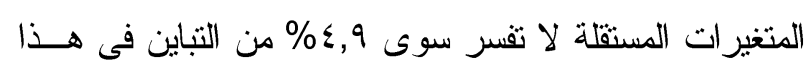

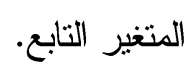

\section{التوصيات}

إستتاداً إلى نتائج البحث يمكن التوصيه بما يلى:-

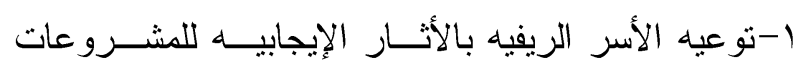

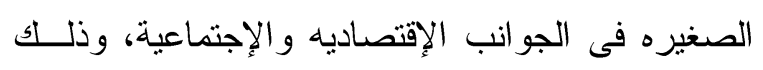

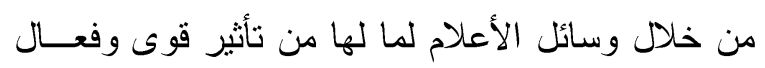
فى إظهار الأثار الإيجابية للمشروعات الصغيرة.

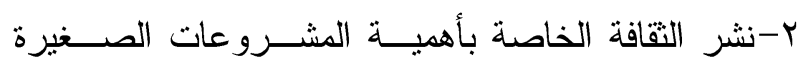

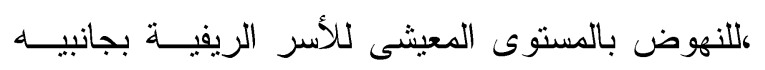
الإقتصادى و الإجتماعى. 


$$
\text { مجلة الإسكندرية للتبادل العلمى - (مجلد Tr العدد ) أكتوبر - ديسمبر } 17 \text {. }
$$

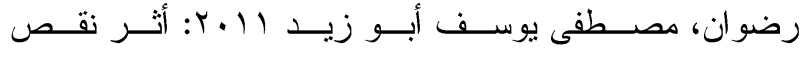

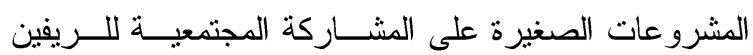

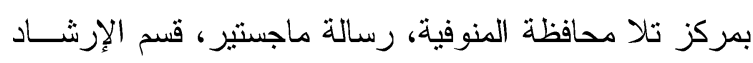

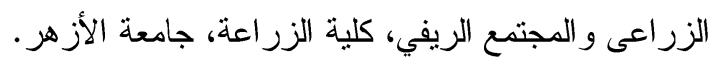
زايد، محمــود 999 ا: دور الإرشــاد الزر اعـــى فــى تتميــة

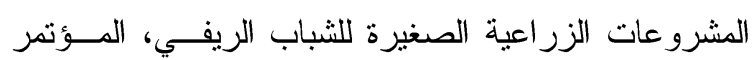

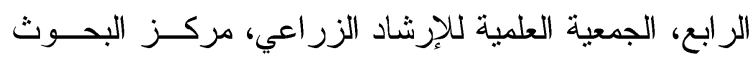

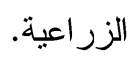

عبد اللطيف، أحمد حلمي ب991: الصناعات الصغيرة وأثزهــا

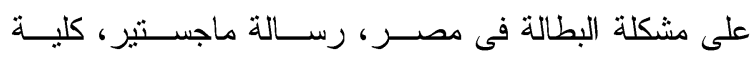
الاقتصاد و العلوم السياسية، جامعة القاهرة.

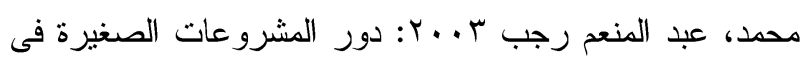
تتمية بعض المناطق الصحر اوية، قسم الاقتصاد الزر اعـي، رئه

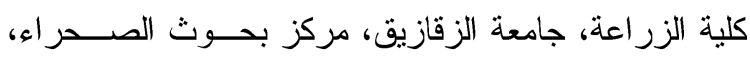

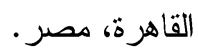

Shames, El-Din, Mohamed, Tomoyuki Yataka jooge Geekim 'Zahigang 'wang and stoshi kai : "The Role of Rural Women in promoting small Industries as an example of socio- Economic Activities" : An over view on the Japanese Eexpriencer Japan, faculty, Agriculture. Kyushu univ 45,.. 335, 347, 2000, (1).

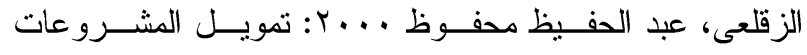
الصغيرة، آلية لمكافحة الفقر و البطالة، مجله بحوث إقتصادية

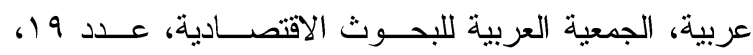

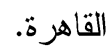

المصرى، غادة عبدالله محمد عامر ب ...r: الآثار الاجتماعيـة

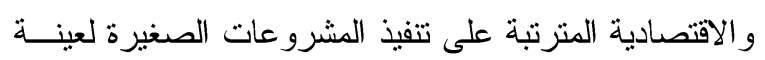
من السيدات فى بعض قرى الخريجين بمنطقة بنجر الســكر، لفئل رسالة ماجستير كلية الزر اعة، جامعة الأسكندرية.

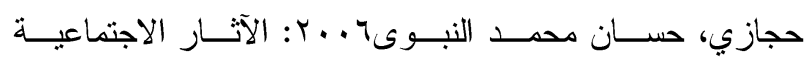

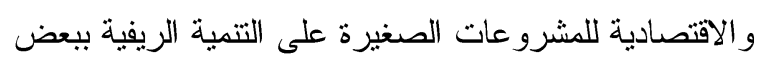

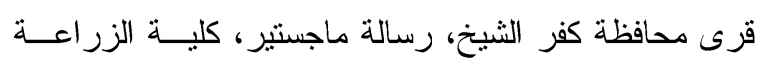
بكفر الثيخ، جامعة طنطا.

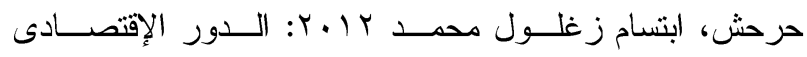

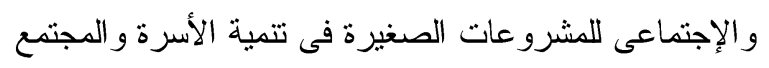
الريفى ببعض قرى محافظة الغربية، رسالة دكتور اه، كليــة

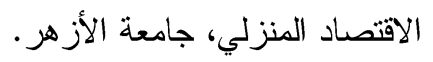

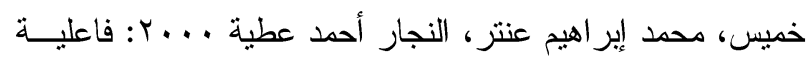
مشروعات الإنتاج الحيوانى التى يقدمها الصندوق الإجتماعى النى

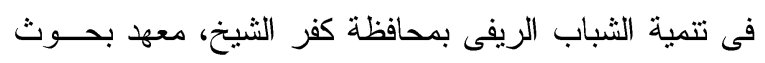

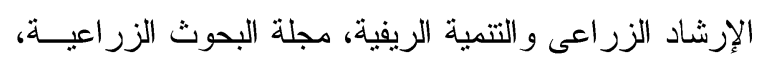

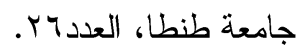




\section{ABSTRACT \\ Social and Economic Impacts of Small Projects in Rural Households (Field Study in Some Village of Kafr-Elshiekh and Algharbia Governorates)}

Enas S. Elsharnooby

This study aims to identify the economic and social impacts of small projects in rural households, as well as the most important obstacles facing these projects, determine the nature of relationship between studied variables and the impact of small projects on economic aspects of rural households; in addition to determine the relationship between independent studied variables and the impact of small projects on the social aspects of rural households. To achieve those objectives Shino and Aryamoon villages in Kafr-Elshiekh Governorate, and Nawag and Shouber in Algharbia Govemorate were selected randomly. Intentional sample of 200 households was selected from households which own small projects in a village bank. The data was collected by through personal interview using a questionnaire from the operator of the project. The percentages, frequencies and simple correlation coefficient (Pearson), multi correlation coefficient and " $\mathrm{T}$ " Test for differences mean in data analysis.

The most important results that conducted from this study were:

- The economic impact of small projects in rural households locates in medium and high category with percent of $85.5 \%$.
- The social impact of small projects in rural households locates in medium and high category with percent of $97 \%$.

- The most important obstacles of working and continuing of small projects, from workers point of view, is the lack of capital that needed for the project $71.5 \%$.

- There was a positive significant relationship between all of: level of education, and participation in formal organizations, and informal social participation, informal, and the level of ambition, and openness geographical, and cultural openness, and the impact of small projects on the economic and social sides.

- There were differences between means of social and economic impacts of small projects for men; additionally there were differences between means of social impacts of small projects for married.

- The results showed that the independent variable interpret together about $21.2 \%$ of the variation of small projects impact in economic side, also the independent variables interpret together about $27.8 \%$ of the variation of small projects impact in social side 